\title{
Transformational change to reduce deforestation and climate change impacts
}

\begin{abstract}
A review of definitions, concepts and drivers in scientific and grey literature
\end{abstract}

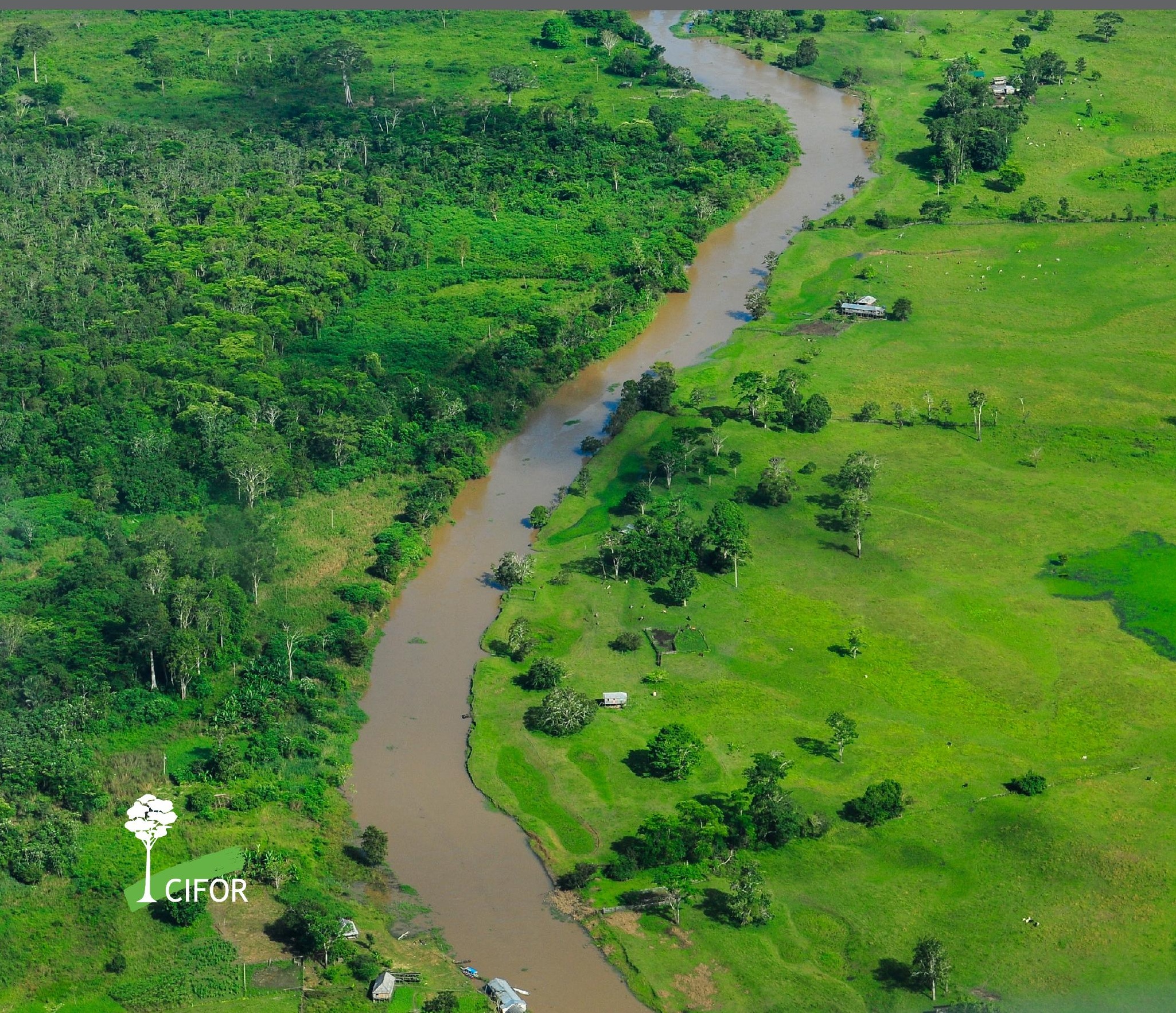





\section{Transformational change to reduce deforestation and climate change impacts}

\section{A review of definitions, concepts and drivers in scientific and grey literature}

Stibniati Atmadja, Christopher Martius, Stephen Leonard

Center for International Forestry Research (CIFOR)

and

Maria José Sanz Sanchez,

Basque Centre for Climate Change (BC3)

Food and Agriculture Organization of the United Nations (FAO)

Rome, 2021 
Required citation:

Atmadja, S., Martius, C., Leonard, S. and Sanz Sanchez, M.J. 2021. Transformational change to reduce deforestation and climate change impacts - A review of definitions, concepts and drivers in scientific and grey literature. Rome, FAO. https://doi.org/10.4060/cb7314en

The designations employed and the presentation of material in this information product do not imply the expression of any opinion whatsoever on the part of the Food and Agriculture Organization of the United Nations (FAO) concerning the legal or development status of any country, territory, city or area or of its authorities, or concerning the delimitation of its frontiers or boundaries. The mention of specific companies or products of manufacturers, whether or not these have been patented, does not imply that these have been endorsed or recommended by FAO in preference to others of a similar nature that are not mentioned.

The views expressed in this information product are those of the author(s) and do not necessarily reflect the views or policies of FAO.

ISBN 978-92-5-135167-3

(c) FAO, 2021

(c) (i) (ㅇ)

Some rights reserved. This work is made available under the Creative Commons Attribution-NonCommercial-ShareAlike 3.0 IGO licence (CC BY-NC-SA 3.0 IGO; https://creativecommons.org/licenses/by-nc-sa/3.0/igo/legalcode).

Under the terms of this licence, this work may be copied, redistributed and adapted for non-commercial purposes, provided that the work is appropriately cited. In any use of this work, there should be no suggestion that FAO endorses any specific organization, products or services. The use of the FAO logo is not permitted. If the work is adapted, then it must be licensed under the same or equivalent Creative Commons licence. If a translation of this work is created, it must include the following disclaimer along with the required citation: "This translation was not created by the Food and Agriculture Organization of the United Nations (FAO). FAO is not responsible for the content or accuracy of this translation. The original [Language] edition shall be the authoritative edition."

Disputes arising under the licence that cannot be settled amicably will be resolved by mediation and arbitration as described in Article 8 of the licence except as otherwise provided herein. The applicable mediation rules will be the mediation rules of the World Intellectual Property Organization http://www.wipo.int/amc/en/mediation/rules and any arbitration will be conducted in accordance with the Arbitration Rules of the United Nations Commission on International Trade Law (UNCITRAL).

Third-party materials. Users wishing to reuse material from this work that is attributed to a third party, such as tables, figures or images, are responsible for determining whether permission is needed for that reuse and for obtaining permission from the copyright holder. The risk of claims resulting from infringement of any third-party-owned component in the work rests solely with the user.

Sales, rights and licensing. FAO information products are available on the FAO website (www.fao.org/publications) and can be purchased through publications-sales@fao.org. Requests for commercial use should be submitted via: www.fao. org/contact-us/licence-request. Queries regarding rights and licensing should be submitted to: copyright@fao.org. 


\section{Contents}

Acknowledgements

iv

Executive summary

$\mathbf{v}$

Summary points

viii

1 Introduction 1

1.1 Scope of the paper 1

1.2 The need for transformational change in land use and climate change 1

1.3 Global discourses and efforts on transformational change in the context of $\begin{array}{ll}\text { climate change, forestry and agriculture } & 2\end{array}$

1.4 Land use, climate change and the need for transformation 3

2 The scientific literature on transformational change 5

2.1 Publication trends and authorship of scientific articles on transformational change 5

2.2 Definition of transformational change and related concepts 5

2.3 Influential theoretical and empirical frameworks for transformational change 8

$\begin{array}{ll}2.4 & \text { Similarities, differences and lessons across multiple sectors } \\ \end{array}$

$\begin{array}{ll}2.5 & \text { Drivers of transformational change } \\ 2.6 & 15\end{array}$

2.6 Indicators of transformational change identified in the literature review $\quad 17$

3 Conclusions $\quad 19$

3.1 Highlights and reflections from reviewing the literature 19

$\begin{array}{lll}3.2 & \text { Issues for further exploration } & 21\end{array}$

References $\quad 25$

$\begin{array}{ll}\text { Glossary } & 31\end{array}$

Annexes 33

1 Method used to select academic literature for review 33

2 List of articles selected for review 34

3 Learning from the land-use sector (agriculture, forestry and other land uses):

Transformational change definitions and concepts that relate to climate change and other disciplines

4 Summary of the drivers of transformational change found in academic literature 44

5 Indicators of transformational change by context and scale of action $\quad 48$ 


\section{Acknowledgements}

We are grateful for the financial support, intellectual contribution and time that the FAO has invested in this report. We especially thank Malgorzata Buszko Briggs, Katherine Clyne, Kristin DeValue, Serena Fortuna, Loreto Sanz Herrera and Thomas Woolnough for their contributions. We also would like to acknowledge additional financial assistance of the CGIAR Research Program on Forests, Trees and Agroforestry (CRP-FTA), with financial support from the donors contributing to the CGIAR Fund. We are grateful to Anne Larson and Maria Brockhaus for reviewing an early version of this report, and to Sarah Oakes for language editing. 


\section{Executive summary}

Humanity is facing a series of critical challenges related to global environmental and climate change. Global development and climate objectives, as enshrined in the Sustainable Development Goals (SDGs), the Paris Agreement and other international efforts, require swift, deep and encompassing action. Climate change must be kept far below the current global average warming trajectory of 3.5 degrees. Evidence is rapidly mounting that, while this may be a herculean task, it is one essential for humanity's survival. There is additional moral and ethical pressure to address large and widening inequalities in income, livelihoods, human health and access to food. Truly 'transformational' change is required that leads to 'paradigm shifts' underpinning the sweeping changes that are needed before 2030, just a few years from now.

In this study, the Food and Agriculture Organization of the United Nations (FAO) and the Center for International Forestry Research (CIFOR) teamed up to investigate how transformational change (transformational change) is understood in the scientific literature. The study, the first of its kind to review academic studies on transformational change, focuses on two main questions: (i) What does 'transformational change' mean? and (ii) What drives it?

We identified and analyzed 111 scientific articles on transformational change in health and business, as well as land use, natural resources and climate change', reviewing articles with the search term 'transformational change' in their titles. This approach ensures articles are representative of the breadth of scientific knowledge directly relevant to discussions on transformational change. We acknowledge that this search could be broadened in the future using related concepts, like 'social change' and 'institutional reform'.

Transformational change is reasonably well articulated and analyzed in health, education and business management literature; likewise, understanding on how transformational change manifests itself in the very long term (e.g. decades and beyond) can be found in the archaeological literature. In comparison, with just 22 papers, literature on transformational change relating to the land-use sector (i.e. agriculture, forestry and other land uses) and climate change remains scarce. The scientific literature published between 2000 and 2018 on transformational change and forestry mostly relates to reducing emissions from deforestation and forest degradation (REDD+).

Scholarship on transformational change specifically within REDD+ and within agriculture (related to climate change adaptation) is relatively new, and substantial contributions have been made from researchers based in developing countries. Overall, however, authors writing about transformational change are mostly affiliated to organizations in just a handful of developed countries (i.e. Australia, Canada, the United Kingdom and the United States,). A broader and better understanding of transformational change requires a broader base of scholarship on the subject; including case studies and analysis of how institutions understand and implement a transformational change-driven agenda.

Other sectors teach us that transformational change is related to human agency - the capacity of humans to act to change a given human or natural environment; either unconsciously and involuntarily, or purposefully and in a goal-oriented manner. The 'how to' literature that deals with organizational change assumes human agency, emphasizing the importance of leadership, political support and cultural/behavioral change. 
Fundamental differences emerge between the various definitions of transformational change, specifically around the type of transformations sought, the unit of transformation, the direction of transformation, time scales and expected leader(s) of transformational change.

Definitions of transformational change have the following in common:

- Transformational change represents a movement away from the current state of affairs, business-asusual regime or behaviors, and an opening of new pathways;

- Transformation should be sustained, either through institutionalization within systems, or changes in behavior, cultures, beliefs and power relations;

- Transformational action should focus on root causes and relationships between dimensions of change (e.g. organizations, markets, technologies, power and social relations, and ideas);

- Knowledge plays a key role, both as driver and indicator of change.

Theoretical frameworks used to analyze transformational change similarly identify some critical elements of successful transformations:

- Collective learning and reflection: learning to inform action, and learning from actions

- Taking and managing risks and expectations: space for innovation, trial and error, and flexibility in program design

- Non-linear thinking that integrates complexity, interconnectedness across multiple dimensions, temporal and spatial scales, and real-time feedback mechanisms

- Consultation and participation: engaging, and consulting with, a wide variety of stakeholders through mechanisms for inclusive, meaningful and enduring participation

- Ownership: e.g. country- or jurisdiction-led approaches; sufficient, flexible and predictable finance

Development interventions are complex, resulting in a dynamic not completely controlled by any one person or institution. As such, interdisciplinary and transdisciplinary learning and collaboration are required, and it is important for actors to recognize that silver-bullet solutions are rare. Instead, it is preferable to embrace a diversity and multiplicity of approaches.

Definitions of transformational change also diverge in several ways. For example, on whether transformational change can be achieved through continuous processes and a series of incremental steps, or whether it instead needs discontinuous/disruptive processes. Some definitions put emphasis on the results of particular actions or investments, or on the process; others put more emphasis on national or large-scale change, as opposed to one-off changes across scales. Many definitions of transformational change do not explicitly highlight multi-level interactions and interdependencies; yet addressing these could be key in transformational change, if it is to address complexity.

Three dimensions of transformational change include the scale, speed and depth of change. Achieving all three dimensions at the same time will inevitably encounter trade-offs among them. It is particularly important that development practitioners and donors understand the time requirements for bringing lasting change. Project lifetimes of less than five years are often too short to have any impact. Projects still need to build on and learn from each other. Since some authors believe speed and urgency to be important elements in transformational change, it is necessary to understand what kind and level of change can be realistically expected under different sets of circumstances.

Transformational change is influenced by drivers; i.e. the short- and long-term forces behind lasting change. Four groups of drivers for transformational change emerged from our literature review: (i) resources: factors that provide the energy needed to push for change; (ii) legitimacy: factors that help change to be accepted by society and its decision makers as an objective that merits the allocation of resources; (iii) processes: actions that harmonize efforts and values across different levels and actors; and (iv) norms: values that guide processes to result in sustainable and transformational collaborations. 
Indicators of transformational change found in scientific articles have a wider scope than those used in monitoring and evaluation practices. Indicators in scientific articles monitor changes across the diverse drivers of transformational change (i.e. resources, legitimacy, processes and norms). These indicators are both level-dependent (i.e. only apply to outcomes at one level), level-independent (i.e. apply to outcomes at multiple levels) and multi-level (i.e. apply to interactions across levels) indicators. In contrast, monitoring and evaluation practices tend to focus only on level-dependent and impact-oriented indicators attributable to one specific actor or action, and not on level-independent and multi-level indicators, or on processes and norms.

Further reflections and scientific analysis are needed on the drivers of transformational change at the intersection between land use and climate change; particularly analysis which focuses on long-term multi-decade impacts. Such analysis will need to account for many unpredictable changes in factors like technology, political and market regimes, demography and ecosystem functions. Guidance is needed on aspects such as: identifying drivers for achieving transformational change at spatial scales that are unique to land uses, like landscapes and watersheds; understanding the financial, human and institutional resources needed to sustain transformational change efforts over very long periods; the practicalities of sustaining the momentum and vision of transformational change across political cycles; and institutional measures to facilitate sustained long-term efforts. Nature-based units of transformation (e.g. landscapes, watersheds, ecosystems) are often challenging and costly to monitor and evaluate. Likewise, multi-level and multisectoral stakeholder coordination and land tenure challenges are unique to land use and climate change.

The literature review presented in this technical paper revealed several issues that need to be further explored, but that were beyond the scope of the present study:

- Transformational change is driven by norms and processes that can either be aligned with, or have trade-offs with, human rights issues. For example, several articles identified that addressing inequalities can drive transformational change. This includes seeking wide participation, empowering marginalized groups, correcting injustices, improving access to information and decision-making processes, and forming a common vision negotiated by all parties. On the other hand - while recognizing the importance of technical knowledge, innovation, and technology - relying on highly technical knowledge can alienate groups who do not have access to that knowledge, limiting their ability to effectively participate in decision making. Transformational change needs to be defined more broadly beyond climate change, and consider the needs of developing countries. Issues of rights are associated with the depth of change as it is concerned with how change and done, by who and for whom; such rights could thus be jeopardized if quick change at scale is the goal. The literature on transformational change supports local ownership in the change process, but does not define 'local ownership' well. There is limited analysis on the trade-offs between processes and norms aligned with improving human rights conditions, and the need to attain resources and legitimacy to drive change. The political economy underlying drivers of transformational changes at the intersection between land use and climate change also needs to be analyzed more deeply and widely.

- Monitoring and measuring transformational change will require new or unconventional methods and indicators that can better deal with complexity and uncertainty. The drivers and dimensions of transformational changes are complex and are often not considered in current monitoring and evaluation $(M \& E)$ approaches. An alternative M\&E approach is needed - one that is applied on multiple scales and depths where transformational change is expected. By identifying transformational change as a dynamic process that needs to remain in motion, impacts can be measured along the way; but only multi-level analysis will allow us to see whether the entire system and all its parts are moving in the right direction. Different types of drivers of transformational change (resources, legitimacy, processes and norms) need to be monitored and are often difficult to measure. Apart from these technical difficulties, there is the issue of legitimacy - i.e. who is considered to be a legitimate actor or entity when it comes to monitoring, evaluation and creating a space to learn from lessons. 


\section{Summary points}

- Use of the term "transformational change", and the science around this term specific to land use and climate change, is still limited. Within the limited literature that exists on transformational change in land use and climate change, work on transformational change in relation to REDD+ appears relatively advanced.

- Existing definitions of transformational change demonstrate similarities in terms of: movement away from the current equilibrium to new pathways, sustained and deep changes, and learning as a driver or indicator of change. However, there are differences of thought in terms of how transformational change can be achieved (i.e. through a continuous process or through incremental steps), what exactly drives transformational change (i.e. particular actions/investments or the process itself), and the necessary scale of change (i.e. national/large-scale or across scales).

- From the literature, drivers of transformational change can be divided into four groups: (i) resources, which provide the energy to push for change; (ii) legitimacy, which helps the change to be accepted; (iii) processes, which harmonize efforts and values across levels and actors; and (iv) norms, which guide processes for sustainable and transformational collaborations.

- Transformational change in the context of land use and climate change is expected to be large-scale, fast and in-depth; but these are arguably unachievable simultaneously. Trade-offs between these three outcomes are likely. Drivers of transformational change in this context require further exploration and analysis.

- What is considered speedy change in climate change and forestry - years and decades - would be considered too slow to be transformational in other disciplines. These lessons need to account for differences in human relationships both within societies and with the natural environment. Both aspects have changed in scale and scope across time.

- Despite academic discussions around the importance of linking different levels to achieve transformational change, most multilateral institutions' definitions do not explicitly highlight multilevel interactions and interdependencies. Such gaps need to be bridged.

- The direction of transformation can be both bottom-up and top-down. Forestry (notably REDD+) literature demonstrates that the engagement of actors at all levels of governance is crucial, and that lack of this engagement has become a barrier for transformational change.

- Stakeholder coalitions that empower and enable transformational change are particularly vital according to land-use and climate change literature, as actors are often fragmented across generations, sector, levels and politics. Conflicts at the policy to local level still dominate, particularly in the land-use sector. 
- Two theoretical frameworks for analyzing transformational change stand out in the area of forestry and sustainability: (i) the $4 \mathrm{I}$ framework, which provides theoretical underpinnings for monitoring and strategizing transformational change in forest policy within developing countries; and (ii) the transition management framework, which was developed in the context of addressing sustainability issues in developed countries.

- New monitoring and evaluation approaches must be developed to account for groups of drivers, since current approaches mostly focus on resource-related outcomes, and rarely on processes, norms or legitimacy. These approaches need to be an integrated part of governance processes to be effective. 


\section{Introduction}

\subsection{Scope of the paper}

Given the urgent need for true transformation to achieve long-term and sustainable reduction in deforestation, and to reach the goals set out in the Paris Agreement, the Food and Agriculture Organization of the United Nations (FAO) and the Center for International Forestry Research (CIFOR) partnered up to generate new knowledge to inform approaches to transformational change. This technical report presents the results of a literature review which aims to answer two fundamental questions: 1 . What does 'transformational change' mean? and 2. What drives it?

The review draws on a broad Transformational Change literature but focuses its reflections and analysis on climate change mitigation and adaptation in the context of forestry, natural resources and agriculture (for ease of reference referred to as 'land use ${ }^{1}$ and climate change' in this document). Agriculture and forestry can provide important nature-based climate solutions; these two sectors alone could contribute over a third of the climate mitigation needed to stabilize global warming to below $2^{\circ} \mathrm{C}$ by 2030 (Griscom et al. 2017).

This review analyzes academic literature, both to capture the most up-to-date theoretical and analytical thinking on transformational change, and to understand how transformational change is defined both within and outside the theme of land use and climate change. To do so, we reviewed 111 scientific journal articles using the term 'transformational change' in their titles. This keyword-based approach is not exhaustive, as many alternative keywords associated with transformational change exist, such as 'social

1 In UNFCCC terminology, land use refers to "Agriculture, Forestry and Other Land Use" (AFOLU); however this technical paper presents reflections only in the context of agriculture, forestry and natural resources. change', 'paradigm shift', 'transformational leadership' or 'institutional reform'. As it leads to a narrow and targeted group of articles, this approach also risks missing relevant work, such as that produced by Tabara and Feola. This targeted approach does however provide a starting point to understand a phrase that is becoming increasingly popular in global climate discourses, with the aim of understanding how transformational change is analyzed, defined and brought about.

Of the 111 journal articles reviewed, 22 were specific to agriculture, forestry and climate change. A description of the methods used to identify the scientific articles included in this review can be found in Annex 1, while the list of reviewed articles is found in Annex 2. This academic literature review was then complemented by a review of the 'grey' literature, published by donors (including the Green Climate Fund and the World Bank), development organizations and practitioners in the field of land use and climate change.

\subsection{The need for transformational change in land use and climate change}

One of the most profound challenges of our time is achieving a sustainable world in a changing climate. The Intergovernmental Panel on Climate Change (IPCC) unequivocally warned of the risks of global warming beyond $1.5^{\circ} \mathrm{C}$ above pre-industrial levels, and identified many of the challenges associated with achieving the Paris Agreement targets (IPCC, 2018b, 2019b). Additionally, lags in the global climate system make warming of more than $2.0^{\circ} \mathrm{C}$ highly likely, at least for some time, if emissions do not peak soon.

Calls for deep changes abound (Klein, 2015; Wallace-Wells, 2019). Unprecedented, rapid and far-reaching transformations are needed in all sectors to achieve a $40-50$ percent reduction in 
emissions by 2030 and a completely carbon-neutral world by 2050 (IPCC, 2018b). Massive worldwide youth demonstrations are drawing attention to the need for bold action, pointing out that they are the ones who will suffer from lack of action by their parents' generation (350.org 2019; Al Jazeera, 2019; Fridays for Future, n.d.). These calls are starting to be heard at high levels. For example, the European Union (EU) is investing in a Green Deal that envisions no net emissions of greenhouse gases by 2050, economic growth decoupled from resource use, and that no person and no place is left behind (EC, n.d.).

Many global efforts attempt to tackle these issues, yet each requires a profound shift in our socioeconomic systems, away from business-as-usual. Linking knowledge to action is essential for this transformation. Successfully addressing the challenges to achieving global sustainability in a complex, intertwined world requires transformative, open knowledge systems and processes. Agendas need to be set collectively, taking into account different perspectives, norms, uncertainties and values. Outcomes need to be evaluated transparently and discussed openly, with participation from a wide range of stakeholders (Cornell et al., 2013).

Notably, discussions on what constitutes transformational change precede the recent advent of the term itself. There have always been attempts to elucidate and operationalize the elements of sustainable transformations. Some examples are still relevant to the discussion, e.g. related to global agriculture (Chapin et al., 2000), dryland development (Reynolds et al., 2007) and environmental conservation (Schindler and Hilborn, 2015).

\subsection{Global discourses and efforts on transformational change in the context of climate change, forestry and agriculture}

Global-level discourses have been echoing the phrase 'transformational change' 2 in the context of land use and climate change. The IPCC's '1.5-degree' report increased the emphasis on the speed of change, by stating with high confidence that "Global warming is likely to reach $1.5^{\circ} \mathrm{C}$ between 2030 and 2052 if

\footnotetext{
The terms 'paradigm shift', 'step change', and 'transitions' are also sometimes being used.
}

it continues to increase at the current rate." (IPCC, 2018a ). Paris Agreement pledges, even if they are met, would result in warming by a catastrophic $3.2^{\circ} \mathrm{C}$ above pre-industrial levels (UNEP, 2019). The depth and speed of the required change implies the need for transformational change. As such, transformational change is given much importance, but it is still a vague concept when applied to climate change and land use.

Differing assumptions, on how climate governance can bring about change and how change should look like, are represented by three streams of global discourse: 'Green governmentality", "Ecological modernization " and "Climate justice" (Bäckstrand and Lövbrand, 2016). Each discourse focuses on different governance problems and beliefs that shape which objectives are selected, and which investments will be made, with very diverse implications for actual transformational change outcomes. Tensions across differing discourses will underlie the way transformational change is realized. Bäckstrand and Lövbrand concluded that there is a discursive compromise between 'Green governmentality' and 'Ecological modernization'. Both discourses largely continue current climate governance and economic regimes, with slight changes. This is contested by the 'Climate justice' discourse, the most critical of the status quo among the three.

Global institutions working on climate change and land use have begun learning about transformational change through several means. The United Nations Development Programme (UNDP) and Climate Investment Funds (CIF) conducted introspective studies to learn from their past activities and examine how transformation change looks within their respective institutional frameworks, as well as what conditions and actions could enable a general movement towards transformational change (UNDP, 2011; Bird et al., 2019; Itad, 2019; CIF and Itad, 2020). These studies have helped institutions conceptualize transformational change more clearly, leading to tools that can be used in practice. For example, CIF's work led to the concept of transformational change 'signals' flagging whether current actions are helping or hindering progress towards transformational change (CIF and Itad, 2020. These signals are not context-specific but can be used to identify more context-specific indicators. Researchers and 
practitioners have also started collaborating on transformational change; for example, CIFOR and FAO began collaborative research into transformational change in the land-use sector and climate change in $2017^{3}$.

Some initiatives engage with a wide variety of stakeholders to share ideas, knowledge and information about transformational change. The Transformational Change Learning Partnership (TCLP), hosted by the CIF, brings together experts and non-experts alike in guided, online, monthly discussion webinars. FAO and CIFOR, through their research collaboration, have organized expert meetings that bring together forestry and climate change experts to exchange views and learn from experiences.

Some institutions have made progress in operationalizing transformational change by establishing practical guidelines that align with their institutional objectives and contexts. Some of these guidelines come from introspective learning processes (e.g. CIF). Germany's Federal Ministry for Economic Cooperation and Development, BMZ, has commissioned guidance documents that use a scientific understanding of transformational change to enhance the impact of capacitydevelopment activities and identify activities for investment (Mersmann et al. 2014), and to design climate finance programs and climate adaptation/ mitigation actions (Mersmann and Wehnert, 2015). GIZ has produced a guidance document for designing 'transformational projects', which elaborates the concept of transformational change and outlines project design principles that lead to transformational change (GIZ, 2020).

Donors have started supporting initiatives specifically to catalyze transformational change. For example, BMZ have launched the 2030 Agenda Transformation Fund (2018) to support short-term (4 - 12 months) and small-scale (EUR 50,000 $125000)$ innovative projects in partner countries. This program aims to create impetus for the transformation needed to achieve the SDGs. As of April 2019, 12 projects were selected, contributing

\footnotetext{
3 The collaboration from which this technical paper, 'Exploring guiding elements of transformational change in integrated landscape management' and an upcoming information brief originate.
}

to the following areas: (i) aligning policies and processes with the 2030 Agenda; (ii) mobilizing domestic resources and private investments for sustainable development; and (iii) capacity building for monitoring and reviewing the 2030 Agenda.

The Green Climate Fund (GCF) has an investment framework that includes six 'initial investment criteria' upon which funding proposals are assessed. One of the six criteria is paradigm shift potential:

"Project proposals should identify a vision for paradigm shift as it relates to the subject of the project. The vision for paradigm shift should outline how the proposed project can catalyze impact beyond a one-off investment. This vision for longer-term change should be accompanied by a robust and convincing theory of change for replication and/or scaling up of the project results, including the long-term sustainability of the results, or by a description of the most binding constraint(s) to change and how it/they will be addressed through the project." (GCF, 2018a)

The GCF also has a Results Monitoring Framework, with four core indicators at the fund level to measure performance against the GCF's paradigm shift objectives to "shift to low-emission, sustainable development pathways" and "increase climate-resilient sustainable development" (GCF, 2018b).

\subsection{Land use, climate change and the need for transformation}

Overall, land use is a significant net contributor to greenhouse gas emissions and climate change (Tubiello et al., 2015; Le Quéré et al., 2018), but it is also a large part of the solution. By 2050, forests and land use will have the potential to mitigate an estimated $13 \mathrm{Gt} \mathrm{CO} 2 /$ year, of which $10 \mathrm{Gt}$ $\mathrm{CO} 2 /$ year are in developing countries (Griscom et al. 2017, 2020; IPCC 2018a, 2019; Dinerstein et al. 2019). Different land-based climate change mitigation options are being debated, along with their environmental and societal implications 
(Griscom et al., 2017; Sanz et al., 2017; Rogelj et al., 2018; Dinerstein et al., 2019). Worldwide, land-based mitigation activities are relied upon for a quarter of the greenhouse gas emission reductions planned by 2030 (Forsell et al. 2016; Grassi et al. 2017; IPCC 2019). ${ }^{4}$

A strategic vision to guide actions is needed, particularly in the land-use sector, with its longer time lags between policy decisions and the materialization of their impacts. This requires a reconsideration of the way we use land, including the planting of crops, using soils, and managing forests and grasslands. Worryingly, even simple technical innovations often take a long time to permeate (IPCC, 2019; Douthwaite, 2002).
Land-based solutions for mitigation of and adaption to climate change require local to global processes. Markets for land, commodities and labor are interconnected at all levels and in all time frames. Scholars of the subject maintain that such multi-scale changes need to be 'transformational' rather than 'incremental', by changing power relations, discourses, attitudes, policies and practices from global to local levels (Bäckstrand and Lövbrand, 2016; Biermann et al. 2012; Brockhaus et al. 2014b). The complexities of climate change and changes in the global socioeconomic environment require 'systems thinking' that includes aspects beyond land-use management itself, like political and economic interests, power structures, and beliefs.

\footnotetext{
4 Based on the information provided in the Intended Nationally Determined Contributions (NDCs) submitted to the UNFCCC
} 


\section{The scientific literature on transformational change}

\subsection{Publication trends and authorship of scientific articles on transformational change}

\begin{abstract}
The number of scientific articles using the title 'transformational change' has been increasing since 2000 (Figure 1). We identified and analyzed 111 scientific articles published before 31 December 2018. Very few were related to agriculture (Jacobs et al., 2017; Mapfumo et al., 2017; Derner et al., 2018), while articles in forestry are mostly on REDD+, and are included within the general environmental science category. Prominent research themes are business and economics (specifically business management), environmental sciences, health, education and public administration. Very few (five) authors are specialists, having contributed more than two articles to this literature (i.e. Babon, Boodoo, Brockhaus, Di Gregorio and Olsen). One author, Valerie Brown, published several books not included in the list of scientific articles (e.g. Brown and Lambert, 2013; Brown and Harris, 2014; Brown and Lambert, 2015).
\end{abstract}

More work is needed to increase the diversity of authorship in transformational change and increase representation among scholars from developing countries. When considering the overall transformational change literature, most (129 of 166) contributing authors were from 19 high-income countries, notably the United States (46 authors), United Kingdom (24 authors), Australia (16) and Canada (14). These four countries account for 61 percent of the authorship in the studied publications. In contrast, 20 authors from 16 low and low-middle income countries account for 9 percent of the authorship. We conclude that the distribution of co-authorship in the transformational change literature is highly skewed against authors in developing countries. The science of transformational change is not yet participatory enough to reflect the voice of authors in developing countries.

\section{While speaking of collaboration, most} transformational change research has not been conducted collaboratively. Very few publications are the result of large, collaborative efforts. Most (58 percent) have one or two authors (Figure 2). Only two papers in fields related to land use and climate change have been written by numerous authors; these are both affiliated to institutions based in developing countries: 20 authors in Brockhaus et al. 2017, and 12 authors in Mapfumo et al. 2017. These two articles represent nearly all the developing country authors active in the study of transformational change.

\subsection{Definition of transformational change and related concepts}

We reviewed the definitions of transformational change found in scientific articles and grey literature, so as to identify similarities and differences (Annex 3) $)^{5}$. In most cases, these are texts that describe - rather than define transformational change or related phrases like 'paradigm shift' and 'transformation'. They are nevertheless useful to extract commonalities and differences in the way transformational change is conceptualized.

Definitions of transformational change share the following common features:

- movement away from the current regime, equilibrium or business-as-usual situation, and opening of new pathways

\footnotetext{
Many of the definitions from the grey literature were identified from Puri (2018)
} 
- sustained changes, either through institutionalization within systems, or changes in cultures, beliefs and power relations

- focus on root causes and on relationships between dimensions of change (e.g. organizations, markets, technologies, power and social relations, and ideas), i.e. deep change

- emphasis on learning, either as a driver or indicator of change.

Some definitions diverge from each other, and we need to work with this diversity. Divergence may be due either to an underlying disagreement of what is transformational and how it is achieved for any goal or context, or to the fact that the goals and contexts require that definitions need to be adjusted. Given the diversity of the literature examined, it is difficult to ascertain the reason for divergence. Examples of divergences are:

- The idea that transformational change can be achieved through continuous processes and a series of incremental steps (Jacobs et al., 2017; Boodoo and Olsen 2018), versus the idea that it can be achieved through discontinuous or disruptive processes (Brown n.d.; Mapfumo et al., 2017).

- Emphasis on the results of particular actions or investments (UNDP, 2011), versus emphasis on the process (Brown n.d.; Holland 2017; Jacobs et al. 2017; Mapfumo et al. 2017).

- Emphasis on national or large-scale change (CIPD, 2015; FAO, 2019; GCF, 2016; GEF, 2018; UNDP, 2011) versus emphasis on changes across scales (Brown, n.d.; Jacobs et al., 2017).

Despite academic discussion around the importance of linking different levels to achieve transformational change ${ }^{6}$, most definitions by multilateral institutions do not explicitly highlight multi-level interactions and interdependencies. Multilateral institutions, typically working in the area of international development, focus on large-scale transformational changes. They set objectives at the higher level based on global agendas, which are used to selectively support action on the ground. It is therefore sufficient to define transformational change based on higher-level changes. Some definitions include country ownership, while others acknowledge heterogeneity among countries; some others set national objectives with national stakeholders. Yet the flow of influence is assumed to be largely limited between national and global scales, with national stakeholders being considered

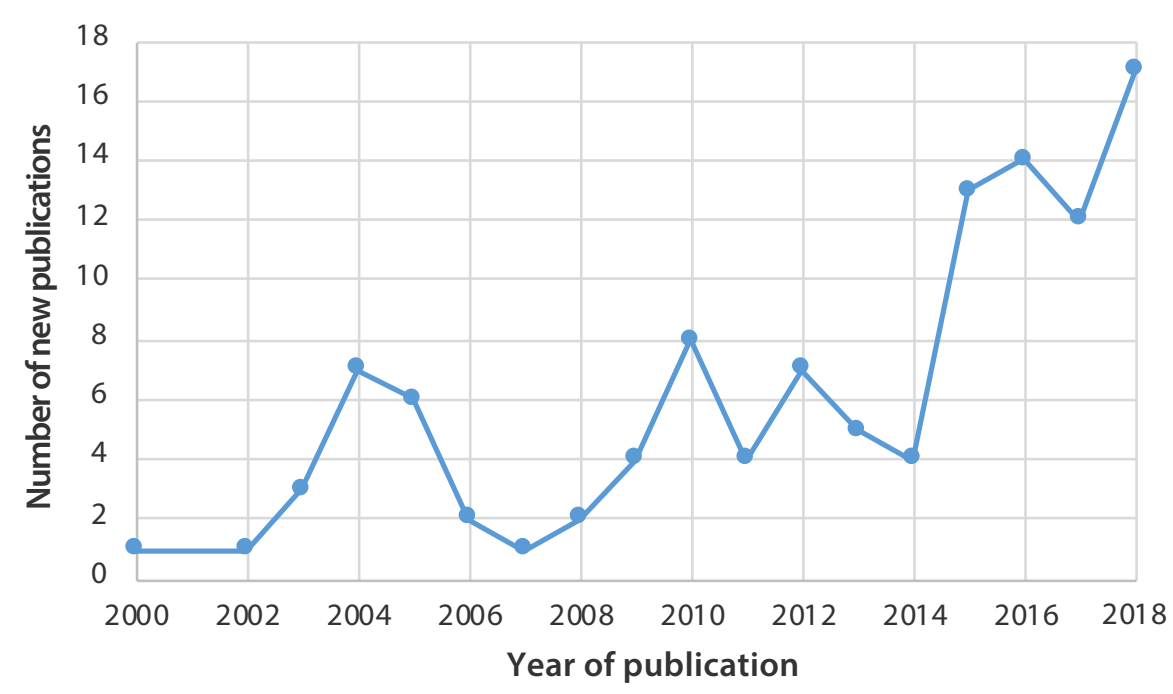

Figure 1. Number of new publications with "transformational change" in their title. Note: As of 31 December 2018, a total of 111 articles were observed

Source: Authors' own elaboration. 


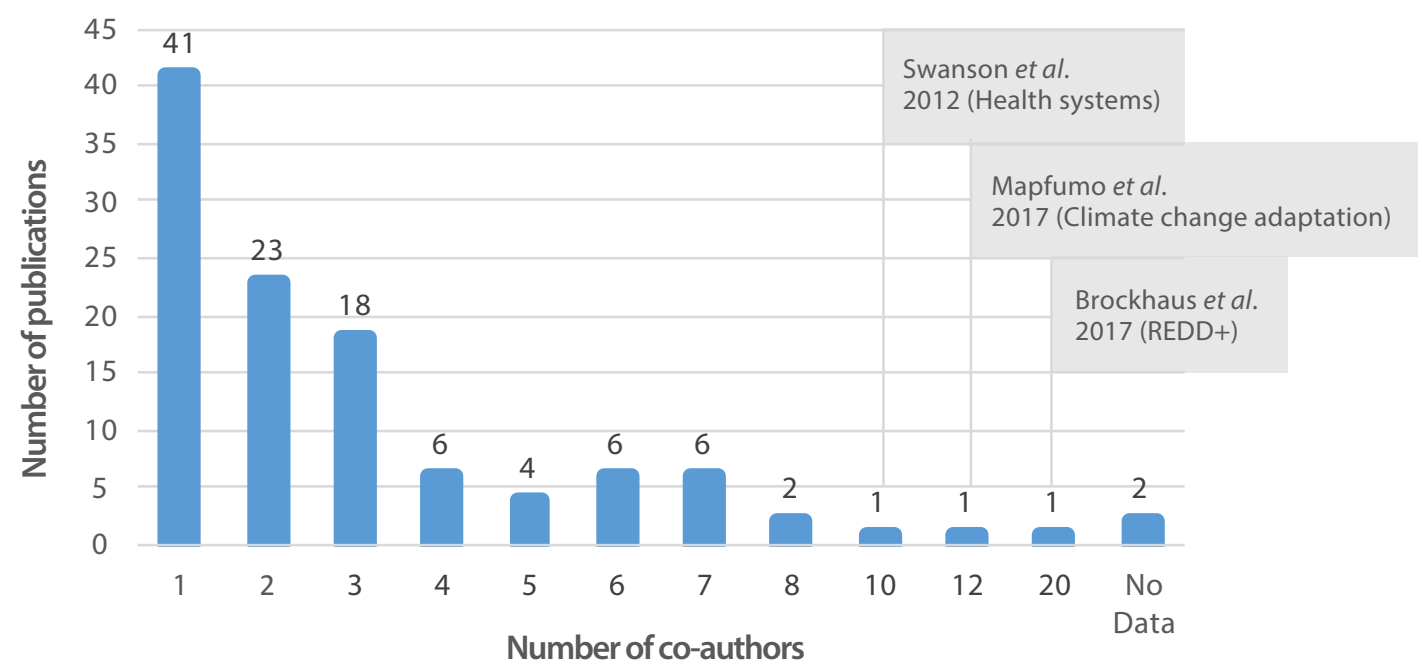

Figure 2. Number of authors listed in publications.

Note: As of 31 December 2018, 111 articles were observed to have 'transformational change' in their titles. There is no data on two of the publications as authors were listed as 'Anonymous'. Source: Authors' own elaboration.

as representing local perspectives ${ }^{7}$. Interactions and interdependencies with and among subnational levels, like local governments and community members, are rarely considered. This results in definitions that are top-down from the perspective of subnational actors.

\section{The gap between multilevel approaches promoted in scientific literature and top- down approaches espoused by global multilateral institutions needs to be} bridged. The scientific literature focuses on the importance of processes, where each scale is an important part of the whole system driving transformational change. Here, every scale matters; there is greater emphasis on animating and managing the non-linear interrelations between scales. This reflects the extensive use of transition management or similar frameworks in the scientific literature, and the desire to find alternatives to the topdown governance systems that often dominate large multilateral institutions (Termeer $e t a l$., 2017; Boodoo et al., 2018). On the other hand, the international institutions that we reviewed focus more on results at one (large) scale. They are interested in attributing how resources provided by their institution can result in

\footnotetext{
With some exceptions, e.g. Mersmann et al. (2014)
}

transformational change. Some scientific articles (e.g. Termeer et al,. 2017; Boodoo et al., 2018) argue that pursuing transformational change is not compatible with top-down governance structures. Others instead acknowledge a discrepancy between ideal transition management approaches to transformational change - which focus on adaptable and participatory management and need easy-to-monitor hierarchical impact pathways for donor accountability on one hand - and the high cost and impracticalities of long-term stakeholder engagement across levels, on the other hand.

By striving to achieve scale, speed and depth simultaneously in transformational change, attempts at transformational change are set to fail. Transformational change in the context of land use and climate change is expected to be large-scale (the whole system instead of isolated parts; inherently multi-dimensional, multi-component, multi-aspectual and multilevel), fast (including jumps and discontinuous processes) and in-depth (fundamental, truly new, revolutionary; with altered values, frames and logics underlying the system). This trifecta was questioned by Termeer et al. (2017): "Although this might be an attractive proposition for people with a change agenda, organization science suggests that achieving all three simultaneously is virtually impossible because of the inherent 
trade-offs between them." (Termeer et al. 2017). As these authors explain, "in-depth change requires people to challenge existing cultures, dominant rationalities and habitual practices, which cannot be enabled through rolling out a large-scale intervention over the whole organization in a standardized way" (Termeer et al. 2017). In the end, achieving two of these goals simultaneously may be possible, but at the expense of the third.

Based on the common features of transformational change, supplemented by suggestions from the scientific literature, we found the following common elements that characterize transformational change in land use and climate change:

Transformational change in land use and climate change is characterized by:

(i) processes that moves away from the current regime of unsustainable land use, maladaptation and unmitigated greenhouse gas emissions, opening pathways to reverse these outcomes and work towards a sustainable planet (ii) being achieved through sustained changes that accept complexity and uncertainty

(iii) a focus on root causes and nurturing relationships between scales and dimensions of change (e.g. organizations, markets, technologies, power and social relations, and ideas)

(iv) being based on participation, equity and transparency

(v) being supported by knowledge and data used for understanding, evaluation and course corrections

\subsection{Influential theoretical and empirical frameworks for transformational change}

Of the 111 articles identified, we focused on a subset of 22 articles on topics related to land use and climate change to understand how transformational change is being analyzed and understood specifically in this context. These 22 articles draw upon several theoretical frameworks from different sciences and apply

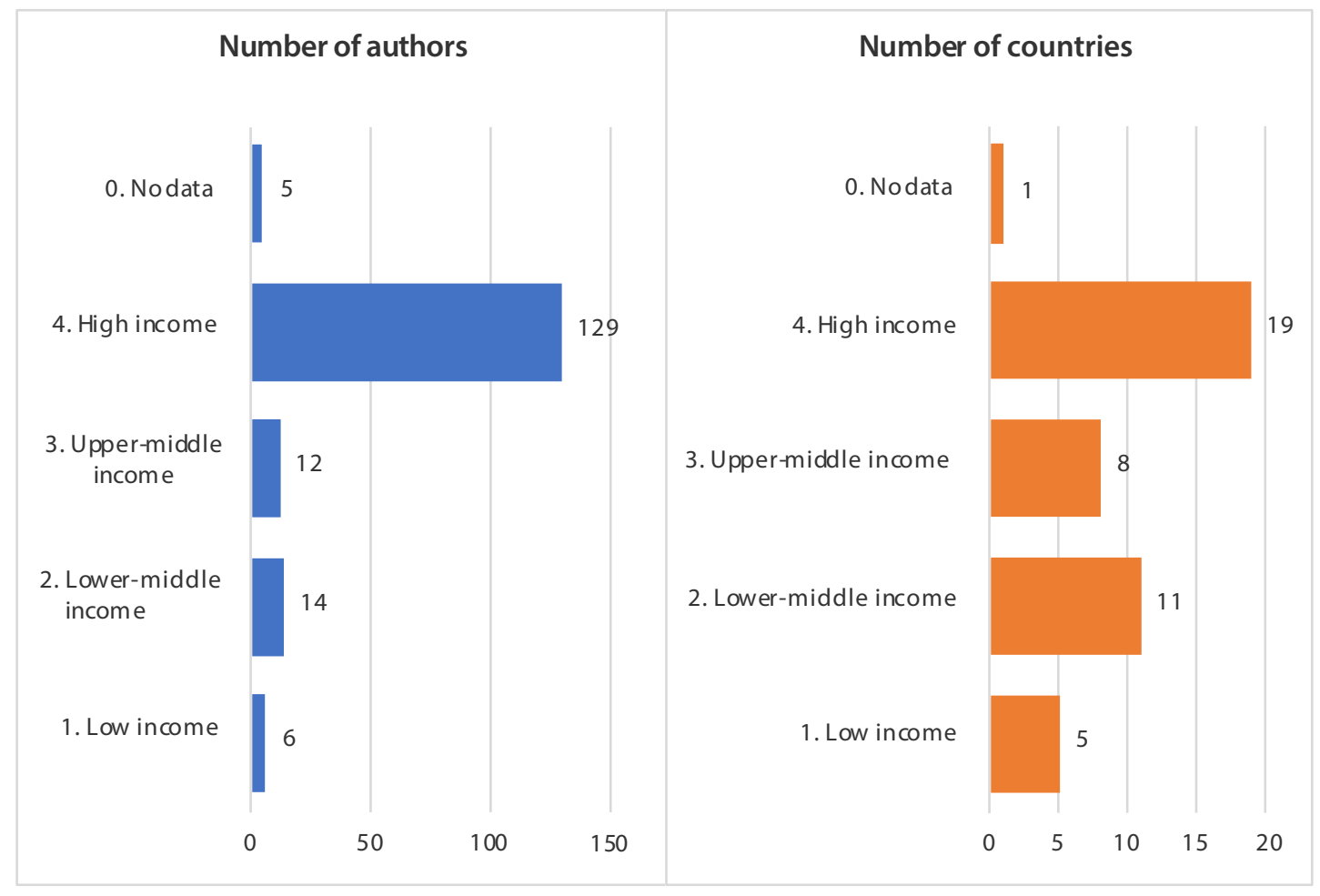

Figure 3. Number of authors by country income classification.

Note: Total number of authors: 166 . Total number of countries: 44. Country income classification taken from https:// datahelpdesk.worldbank.org/knowledgebase/articles/906519-world-bank-country-and-lending-groups, accessed 15 September 2020. Countries represent authors' affiliations, not their citizenship.

Source: Authors' own elaboration. 
different analytical frameworks and definitions to analyze transformational change. Within this heterogeneity, there is general agreement about the critical elements of moving towards transformational change:

- Importance of creating space for innovation (either technical or institutional), trial and error, and flexibility in program design.

- Moving away from linear cause-and-effect logical frameworks towards non-linear thinking that integrates complexity, interconnectedness across multiple dimensions, temporal scales and spatial scales, and feedback mechanisms (i.e. systems thinking).

- Engaging a wide variety of stakeholders, with emphasis on meaningful participation and the inclusion of marginal stakeholders and connecting traditionally disconnected groups of stakeholders.

- Emphasizing the use of learning to inform action and learning from actions by monitoring processes and outcomes and using feedback mechanisms, as well as collective learning and reflection.

We detected influential theoretical and empirical frameworks of transformational change by identifying large (i.e. three or more) clusters of studies that adopt the same framework or set of methods. Two clusters of studies emerged. The first cluster of studies adopt the transition management framework (see Annex 4), described in Loorbach (2010). This transition management cluster of studies includes articles by McAlpine et al. (2015), Fridahl and Johansson (2017), Jacobs et al. (2017), Mapfumo et al. (2017), Boodoo and Olsen (2018) and Boodoo et al. (2018).

The second cluster of studies focuses on REDD+ (Babon et al., 2014; Korhonen-Kurki et al., 2014; Moeliono et al., 2014; Di Gregorio et al., 2015; Brockhaus et al., 2017) and - more recently Moeliono et al (2020). The REDD+ cluster of studies adopted a consistent analytical framework and methods to study transformational change developed under the Global Comparative Study on REDD+ led by CIFOR. These studies focus on same key elements, which are transformational change as a change in discursive practices, incentive structures and power relations. They also follow the same definition of transformational change described in Brockhaus and Angelsen (2012). These methods and definition were used almost exclusively in the context of REDD+ and forest governance, and influenced the work of other researchers (e.g. Ngendakumana et al. 2014; Glover and Schroeder 2017; Chia et al. 2019).

Transition management was developed for a wide range of sustainability issues across a range of natural resources (e.g. water, minerals, and soil health), whereas the REDD+ studies took a political economy perspective on change (or lack thereof) to the underlying drivers of deforestation and forest degradation, with REDD+ as a case study. The underlying frameworks used by these two clusters of studies are complementary, as the transition management framework offers concrete 'how-to' guidelines, while the REDD+ studies focus on the underlying (political economy) conditions that determine the direction and likelihood of change away from the business-asusual state of deforestation and forest degradation.

\subsubsection{Transition management framework}

Transition management is a governance approach for sustainable development based on complexity theory, in particular two theories of how societies and technologies transition: (i) the multilevel perspective (Rip and Kemp 1998; Geels 2002) that distinguishes innovations at three levels: niches, regimes and landscapes; and (ii) the multiphase or S-curve model (Rotmans et al. 2001) that distinguishes between phases of innovation: predevelopment, take-off, acceleration and stabilization phases. Transition management is rooted in the transition sustainability literature (reviewed in Markard et al. 2012), which in turn builds on complexity science (Boodoo et al. 2018). Complexity science has been used to design programs for transformational change at various levels, including at the community level (e.g. Brown and Lambert 2013; Durie and Wyatt 2013). The basic tenet is that changes must come from selforganization and relationships within the system.

Transition management can be used to analyze and govern societal processes. Table 1 describes the types of activities that transition management suggests for bringing about transformational change at difference levels and their focus.

Activities to bring about transformational change interact and exist simultaneously at different levels and time scales. Reflexive actions are the glue that brings these levels together. Researchers play a central role in reflexive action, as they analyze 
longer-term societal processes and dynamics and put these on the societal and political agenda. Reflexive actions are necessary to prevent lockin and enable exploration of new ideas and trajectories.

Reflexive action:

- includes monitoring, assessments and evaluation of ongoing policies, and ongoing societal change,

- is found in existing institutions (e.g. monitoring and evaluation units, learning forums) or is socially embedded (e.g. media, internet),

- needs to be an integrated part of governance processes.

Transition management's advantage is that it provides a 'how to' general guide for transformational change that can be applied to a wide range of long-term societal issues (See Box 1). The approach is useful for planning and developing a theory of change (Martius et al. 2018) for each context, because it advocates for building a shared image of the future, establishing an agenda and pathway for transitions, and using experimentation, monitoring and evaluation to provide evidence-based decisions towards change.

Critics of the transition management approach (e.g. Shove and Walker 2016) point to several weaknesses, like the lack of consideration of the politics of managing transitions. For example, transition management proposes the establishment of a transition arena consisting of 10-15 people to structure the problem, develop a vision and organize the arena (see Box 1). However, the framework leaves gaps in the political economy of transformational change, like who decides who will participate, what makes the transition arena legitimate, the source of resources for such an enterprise, how to engineer the demise of undesirable technologies, and reliance on controlling (in reality, uncontrollable) uses of innovations to push for transformation.

\subsubsection{REDD+ political economy framework}

The REDD+ political economy framework was developed in CIFOR's Global Comparative Study on REDD+ (GCS REDD+) to understand and overcome challenges in achieving transformational change in REDD+. In this framework, REDD+ is seen both as potential game-changer (i.e. a driver of change) and a beneficiary of up-front changes and changes in other sectors. Research on transformational change has focused on the REDD+ policy arena as the place where a network of actors come together, negotiate and influence each other (CIFOR, 2020). This REDD+ policy arena is characterized by a multitude of actors from global to local levels, and has some features that make transformational change challenging (Brockhaus and Angelsen, 2012):

- multilevel institutions and multilayered processes (e.g. funding, forest governance, REDD+ coordination, cross-sectoral coordination);

- multiple actors with different authorities, interests, discourses, beliefs and modes of thinking;

- a variety of governance structures, in the form of hierarchies, coalitions or networks, along the spectrum between markets and states;

- context dependence, implying that changes outside the forestry sector are needed to achieve REDD+ objectives.

A framework called the 4I framework was developed as part of the GCS REDD+ (see Brockhaus and Angelsen, 2012). It provides the theoretical underpinnings for investigating business-as-usual circumstances, strategizing and monitoring for transformational change in forest policy in developing countries. The framework has four components:

- Institutions, which form the 'rules of the game' consisting of norms, regulations and other formal and informal arrangements. Historically, institutions have enabled the current trend of forest degradation and loss. State institutions (e.g. ministries, agencies) and private companies are especially influential in the forestry sector. Institutional change is restricted by path-dependencies (i.e. 'what was' and 'what is' are shaped by 'what can be') and stickiness (i.e. resistance to change, notably among state organizations).

- Interests of actors in efforts to halt or continue forest loss. In the business-as-usual scenario, there are limited interests to change, although this may change over time as other factors change (e.g. institutions, incentives, ideas). One way to realize interests in change is to build coalitions among different actors to leverage their combined political and economic powers. There are conflicting interests and tradeoffs across and within actor groups, which can be conducive for progress (Brockhaus 
Table 1. Transition management levels and their focus.

\begin{tabular}{|c|c|c|c|c|}
\hline $\begin{array}{l}\text { Transition } \\
\text { management } \\
\text { governance } \\
\text { level }\end{array}$ & Transformational change challenge & $\begin{array}{l}\text { Target of } \\
\text { action for } \\
\text { transformational } \\
\text { change }\end{array}$ & $\begin{array}{l}\text { Time } \\
\text { scale }\end{array}$ & $\begin{array}{l}\text { Example of activities } \\
\text { for transformational } \\
\text { change }\end{array}$ \\
\hline Strategic & $\begin{array}{l}\text { Deep, slow-changing and exogenous } \\
\text { structural trends that exert a } \\
\text { unidirectional influence on the regime } \\
\text { and niche dynamics }\end{array}$ & $\begin{array}{l}\text { Culture and } \\
\text { societies }\end{array}$ & $\begin{array}{l}\text { Long- } \\
\text { term } \\
\text { ( } 30 \\
\text { years) }\end{array}$ & $\begin{array}{l}\text { Establishing a } \\
\text { transition arena; } \\
\text { structuring problems; } \\
\text { envisioning of futures }\end{array}$ \\
\hline Tactical & $\begin{array}{l}\text { Stable socio-technical configurations } \\
\text { that depict the established way of } \\
\text { doing things, which, in turn, hinder the } \\
\text { development of innovative ways to } \\
\text { fulfil societal functions termed 'niches' }\end{array}$ & $\begin{array}{l}\text { Structures/ } \\
\text { institutions }\end{array}$ & $\begin{array}{l}\text { Mid- } \\
\text { term } \\
(5-15 \\
\text { years) }\end{array}$ & $\begin{array}{l}\text { Building coalitions; } \\
\text { developing images } \\
\text { and transition } \\
\text { agendas; developing } \\
\text { transition scenarios }\end{array}$ \\
\hline Operational & $\begin{array}{l}\text { Protected spaces where unstable but } \\
\text { more sustainable practices may be } \\
\text { nurtured to challenge existing ones }\end{array}$ & Practices/projects & $\begin{array}{l}\text { Short- } \\
\text { term } \\
(0-5 \\
\text { years })\end{array}$ & $\begin{array}{l}\text { Mobilizing actors; } \\
\text { executing activities }\end{array}$ \\
\hline Reflexive & $\begin{array}{l}\text { Lack of reflexiveness prevents different } \\
\text { levels of governance from interacting }\end{array}$ & All levels & $\begin{array}{l}\text { All time } \\
\text { scales }\end{array}$ & $\begin{array}{l}\text { Monitoring of the } \\
\text { process; evaluation } \\
\text { and re-orientation }\end{array}$ \\
\hline
\end{tabular}

Source: Adapted from Loorbach 2010 and Boodoo and Olsen 2018

and Di Gregorio, 2014). The presence of a powerful 'transformational coalition' in REDD+ countries is a crucial ingredient for larger transformation (Korhonen-Kurki et al., 2019).

- Ideas (concepts or mental constructions), ideologies (a normative set of ideas), and beliefs about how forests should be managed, help legitimize actions for or against change. The extent to which beliefs resist change vary. In some contexts, a policy proposal can touch non-negotiable beliefs and is therefore rejected, e.g. carbon offsetting. In other contexts, the same proposal speaks to beliefs in the dominant economic framework and hence opens space for negotiation. How a problem is

\section{Box 1. Summary of the transition management approach}

1. Organize the transition arena:

- Create a group of 10 - 15 individuals, not representing institutions, who are willing to invest time in structuring the problem, developing a long-term sustainability vision and establishing and organizing the transition arena.

- These individuals need to represent various perceptions of the problem, as well as possible solutions.

- The group is a network of innovation, not an administrative platform or consultative group.

- They should consist of an equal number of frontrunners from the government, the private sector, NGOs, knowledge institutes and intermediaries (consulting organizations, project organizations and mediators).

- They are selected by experts on the process and the transition subject (e.g. climate change, forestry, agriculture).

2. Develop future images and a transition agenda, and derive the necessary transition paths.

3. Establish and carry out transition experiments, and mobilize the resulting transition networks.

4. Monitor, evaluate and learn from the transition experiments and, based on these lessons, make adjustments in the vision, agenda and coalitions. 
framed limits the options of what seems to be reasonable or possible, and hence shapes policy action or justifies inaction.

- Information or knowledge, upon which discourses unfold. Information is diverse, can be conflicting, and can be used to justify action or non-action. There is also a political dimension in what seems to be a technical issue that is especially pertinent in forestry, as the wide variety of actors (including companies, ministries, scientists, and local communities) have different capacities to access, process and provide information. Often, facts are used to support the interests of the information provider, which is one of the reasons why there are many (often conflicting) discourses on climate change and forests. Information can either constrain or enable change, depending on who uses it, and how it is used (Myers et al., 2018).

\subsection{Similarities, differences and lessons across multiple sectors}

\section{Given the small amount of academic literature} on transformational change in land-use and climate change (22 papers), we must learn from other sectors. Bringing about transformational change depends mainly on how it is defined, the kind of 'change' envisaged, and the roles and types of stakeholders involved. These are very contextual questions; hence, from the outset, opportunities to learn from other fields must be treated with great care. The first step is to identify differences and similarities. To do so, we grouped the 111 articles into six themes: three directly related to the specific interest (land-use and climate change research themes - agriculture, forestry and climate change adaptation and mitigation); and three themes that are the most prominent in the transformational change literature (i.e. health, education, business management). An additional research theme - public administration - cuts across the six themes and was not analyzed. These themes are characterized by the type of transformation sought, the scale of transformation, the time scale, the direction of transformation, and the expected leader of transformational change. This analysis is based on the information provided in the abstracts of 111 transformational change articles, summarized in Table 2 . The following characteristics set land-use and climate change literature apart from other themes (education, health, business management) and can be the basis of further research that is targeted at the land-use sector:

- topics of land tenure are more prominently discussed,

- units of transformation include those that are based on the natural environment (e.g. watershed, ecosystem, biome, landscapes),

- nature has a stronger influence on transformational change outcomes,

- time scales are longer, especially in forestry and climate change,

- the literature rarely provides hands-on practical advice on how to bring about transformational change.

There was no significant difference in the way transformational change was defined in landuse and climate change literature. All research themes are similarly cognizant of the importance of collaboration and learning across public and private actors, and across levels for transformational change. This is particularly the case in forestry.

What is considered speedy change in climate change and forestry - years and decades - would be considered too slow to be transformational in other disciplines. Because of this, the archaeology and history literature, especially that which analyzes transformations in human civilizations due to climate change, can offer valuable insights into how humans can cause transformational change in the long run, and the impact of undertaking transformational change for future generations (see Hassan 2009; Schoon et al. 2011). These lessons need to account for the difference in human relationships, both within societies and with the natural environment. Both aspects have changed in scale and scope across time.

The direction of transformation is both bottomup and top-down. The forestry (notably REDD+) literature demonstrates that the engagement of actors from all levels of governance is crucial, and that lack of this engagement has become a barrier for transformational change (see, for example, Babon et al. 2014). Climate change adaptation literature provides examples of bottomup transformations, like collective action by citizens and local governments to improve climate resilience (e.g. Mapfumo et al., 2017; Totin et al. 2018). The climate change mitigation literature, excluding REDD+, provides examples of top-down processes like climate finance (e.g. Boodoo and Olsen 2018; Boodoo et al. 2018). 
Transformational change analysis in business and management is well-developed and offers practical insights into institutional transformation; however, many messages are lost in translation due the more complex types of stakeholders, objectives, visions, time frames and constraints in land use and climate change. There is a wide range of management books, training courses and research papers on how to bring about, sustain and endure transformational change within organizations. This literature offers the needed 'how to' that is lacking in transformational change literature on land use and climate change, like how to cultivate leaders and an organizational culture that enables transformational change. The business management literature focuses more on transformational change within enterprises and smaller units, making its findings useful for ministries, programs, projects, departments, communities and individuals. There are increasingly more articles going beyond profitmaximization, and into social and environmental sustainability. Nonetheless, the literature lacks guidance for very long-term and global-level transformations relevant to addressing climate change, and the direction of transformation is almost exclusively top-down.

\section{Transformational change research in public administration, health and education offers numerous learning opportunities for transformational change in land use and climate change due to similar interests in improving the governance of systems and public institutions.} The education literature provides a rich source of information on how to improve personal and collective learning. The health literature is interested in improving service delivery by providing integrated care from different service providers. Transformational change analysis in the public administration literature is well developed in practical and analytical terms, and applicable to a wide range of transformational change objectives in land use and climate change due to its emphasis on improving governance and on the inclusion of bottom-up transformation pathways.

\section{Transformational change articles in the} education sector offer practical methods for learning at the personal and communal level, and analysis on the process of institutional change at the national to school level. Compared to the land-use and climate change literature, the educational literature on transformational change benefits to a deeper extent from the fields of psychology at the individual level. At the institutional level, it often draws from the field of management, organizational behavior and public administration (e.g. Ananthakrishnan et al. 2012; Kezar 2013; Boone 2015). One example of practical methods to bring change in this literature is Kezar (2013), who examined 28 universities in the United States. They found that sensemaking/sensegiving processes (e.g., activities to 'give sense' to or 'make sense' of a problem or experience) determined success in achieving transformational change objectives such as creating interdisciplinary learning environments. Previous work (Kezar and Eckel 2002) identified five core strategies facilitating sensemaking/sensegiving support from senior administration, collaborative leadership, staff support, taking action and robust design. These strategies gave key participants the opportunity to create a new sense of the direction and priorities for the institution. Widespread conversations, cross-departmental teams, public presentations and external speakers were pivotal tools to create sensemaking.

\section{All fields grapple with the issue of top-down} and bottom-up change processes, and multistakeholder linkages. In the field of education, the multi-level relationship between ministries of education, university or school administration and faculty/staff reflects to some extent the relationship between the different levels of government and local people in the land-use and climate change context. The same is reflected in health and business management. Forming linkages across these various levels and stakeholders is important for transformational change in any field. While these insights are important, there are significant differences in the prominence and role of government, private sector and civil society, which are specific to each field. Applying approaches from other fields (e.g. sensemaking/sensegiving in Kezar and Eckel [2002]) would need to account for the different constellation of actors.

Land-use and climate change studies focus more on learning at the institutional and communal level, rather than at the personal level, reflecting the collective nature of land use and climate change. Some articles (e.g. Amansure and Adendorff, 2018) view education as an intervention that can lead to transformational change, in the form of formal and informal learnerships, mentorships, further education and 
Table 2. Summary of type, unit, direction and expected leader of transformational change across research areas (based on literature review).

\begin{tabular}{|c|c|c|c|c|c|}
\hline $\begin{array}{l}\text { Research } \\
\text { theme }\end{array}$ & $\begin{array}{l}\text { Type of } \\
\text { transformations } \\
\text { sought }\end{array}$ & $\begin{array}{l}\text { Unit of } \\
\text { transformation }\end{array}$ & $\begin{array}{l}\text { Time } \\
\text { scale }\end{array}$ & $\begin{array}{l}\text { Direction of } \\
\text { transformation }\end{array}$ & $\begin{array}{l}\text { Expected } \\
\text { leader of } \\
\text { transformational } \\
\text { change }\end{array}$ \\
\hline $\begin{array}{l}\text { Climate } \\
\text { change }\end{array}$ & $\begin{array}{l}\text { Reduced greenhouse } \\
\text { gas emissions, reduced } \\
\text { impact of climate } \\
\text { change, improved use } \\
\text { and governance of } \\
\text { natural resources }\end{array}$ & $\begin{array}{l}\text { Countries, world } \\
\text { In terms of } \\
\text { adaptation: } \\
\text { households, } \\
\text { communities, } \\
\text { jurisdictions }\end{array}$ & $\begin{array}{l}\text { Decades, } \\
\text { centuries }\end{array}$ & $\begin{array}{l}\text { Top-down } \\
\text { (e.g. climate } \\
\text { financing); } \\
\text { bottom up } \\
\text { (especially for } \\
\text { adaptation) }\end{array}$ & $\begin{array}{l}\text { Government, } \\
\text { local } \\
\text { communities, } \\
\text { NGOs, donors, } \\
\text { global } \\
\text { institutions }\end{array}$ \\
\hline $\begin{array}{l}\text { Forestry } \\
\text { (and natural } \\
\text { resource } \\
\text { management) }\end{array}$ & $\begin{array}{l}\text { Increased forest cover/ } \\
\text { quality, carbon- and } \\
\text { non-carbon benefits } \\
\text { (economic, social, } \\
\text { environmental, climate } \\
\text { change), cross-sectoral } \\
\text { coordination }\end{array}$ & $\begin{array}{l}\text { Households, } \\
\text { communities, } \\
\text { jurisdictions, } \\
\text { watersheds, } \\
\text { landscapes, } \\
\text { ecosystems, } \\
\text { sectors, countries, } \\
\text { world }\end{array}$ & Decades & $\begin{array}{l}\text { Top down } \\
\text { (e.g. national } \\
\text { or landscape } \\
\text { programs); } \\
\text { bottom-up } \\
\text { (e.g. collective } \\
\text { action) }\end{array}$ & $\begin{array}{l}\text { Government, } \\
\text { enterprises, local } \\
\text { communities, } \\
\text { NGOs, donors }\end{array}$ \\
\hline Agriculture & $\begin{array}{l}\text { Increased and } \\
\text { sustainable agricultural } \\
\text { production, } \\
\text { benefits (income, } \\
\text { health, climate } \\
\text { change); reduced } \\
\text { environmental impact } \\
\text { per unit produced }\end{array}$ & $\begin{array}{l}\text { Individuals, } \\
\text { households, } \\
\text { communities, } \\
\text { jurisdictions, } \\
\text { watersheds, } \\
\text { sectors, } \\
\text { commodity, } \\
\text { countries, } \\
\text { enterprises, world }\end{array}$ & $\begin{array}{l}\text { Seasons, } \\
\text { years }\end{array}$ & $\begin{array}{l}\text { Top down (e.g. } \\
\text { national or } \\
\text { commodity } \\
\text { programs; } \\
\text { technology } \\
\text { adoption } \\
\text { programs); } \\
\text { bottom-up } \\
\text { (e.g. collective } \\
\text { action) }\end{array}$ & $\begin{array}{l}\text { Government, } \\
\text { enterprises, } \\
\text { donors, local } \\
\text { communities }\end{array}$ \\
\hline Education & $\begin{array}{l}\text { Learning efficacy, } \\
\text { suitability with job } \\
\text { market/sectors, } \\
\text { management } \\
\text { efficiency, } \\
\text { interdisciplinary } \\
\text { learning }\end{array}$ & $\begin{array}{l}\text { Individuals, } \\
\text { enterprises (e.g. } \\
\text { schools, service } \\
\text { providers), } \\
\text { communities, } \\
\text { school systems, } \\
\text { sectors, sub- } \\
\text { sectors (e.g. fields } \\
\text { of expertise), } \\
\text { world }\end{array}$ & $\begin{array}{l}\text { Months, } \\
\text { years }\end{array}$ & $\begin{array}{l}\text { Top down (e.g. } \\
\text { education } \\
\text { system reform), } \\
\text { bottom up }\end{array}$ & $\begin{array}{l}\text { Government, } \\
\text { enterprises, local } \\
\text { communities, } \\
\text { professionals, } \\
\text { individuals }\end{array}$ \\
\hline $\begin{array}{l}\text { Business } \\
\text { management }\end{array}$ & $\begin{array}{l}\text { Increased profitability } \\
\text { and sustainability }\end{array}$ & $\begin{array}{l}\text { Individual staff, } \\
\text { leaders within } \\
\text { enterprises, entire } \\
\text { enterprises }\end{array}$ & $\begin{array}{l}\text { Months, } \\
\text { years }\end{array}$ & Top-down & Individuals \\
\hline Health & $\begin{array}{l}\text { Improved health } \\
\text { service, reduced } \\
\text { cost, clinical } \\
\text { efficacy, improved } \\
\text { coordination, } \\
\text { evidence-based } \\
\text { approach }\end{array}$ & $\begin{array}{l}\text { Individuals, } \\
\text { enterprises (e.g. } \\
\text { hospital/clinic, } \\
\text { service providers) } \\
\text { communities, } \\
\text { health system, } \\
\text { health sector, } \\
\text { world }\end{array}$ & $\begin{array}{l}\text { Months, } \\
\text { years }\end{array}$ & $\begin{array}{l}\text { Top down } \\
\text { (e.g. health } \\
\text { system reform); } \\
\text { bottom up (e.g. } \\
\text { integrating } \\
\text { parents in } \\
\text { care of child } \\
\text { patients) }\end{array}$ & $\begin{array}{l}\text { Government, } \\
\text { enterprises, local } \\
\text { communities, } \\
\text { professionals, } \\
\text { individuals }\end{array}$ \\
\hline
\end{tabular}


training, educational support and resourcing. It is imposed externally, as part of the context within which actors operate. Several articles focus on collective or transformational learning processes (e.g. Brown and Lambert, 2013 and 2015), drawing heavily on theories related to education and epistemology. This body of work has identified methods and tools to encourage learning, mainly at the local level.

Establishing links between these different stakeholders is an important aspect of transformational change in the land-use and climate change literature, because actors in the land-use sector are fragmented. Transformational change requires coalescing power from different actors which are strewn across generations, sectors (e.g. between forestry, agriculture, land administration), levels (global to local), and political boundaries. They have asymmetric power (weak to strong) and draw from different sources of knowledge (practical, theoretical). Several types of linkages are being discussed in the literature that link some of these different pockets of actors: advocacy coalitions that can either promote or hinder transformational change in forest governance (e.g. Babon et al., 2014; Brockhaus et al., 2017); social, technical and political coalitions built around coordinated activities to manage a common resource (like urban water, e.g. Bos et al., 2015); partnership between scientists and land managers (Derner $e t$ al., 2018); and a coalition of 'prime movers' built through consensus among policy makers, institutions and scientists (Jacobs et al., 2017).

\section{Land-use and climate change studies} demonstrate the importance of enabling and empowering coalitions with desire to achieve transformational change, while highlighting some challenges. These include: conflicts at the policy level where powerful actors derive and maintain power; conflicts at the local level where ideas become action that impacts daily lives; market forces overcoming socially desirable goals through profit; the relative weakness of coalitions that demand change versus those that want to maintain the status quo; and difficulties in changing institutions, even if there is political will and consensus to do so among actors (Babon et al., 2014; Brockhaus et al., 2017; Jacobs et al., 2017).
Identifying appropriate stakeholders is vital in transformational change strategies due to the importance of linking stakeholders together and building coalitions. This is particularly true in land use and climate change, where there are strong competing interests between and within landuse sectors. Studies analyzing transformational coalitions in REDD+ policy networks can be a useful starting point.

\subsection{Drivers of transformational change}

\subsubsection{Basic concepts}

The following definitions were taken from the transformational change literature.

Drivers are underlying and proximate conditions and the forces that influence the outcome of actions. This definition is inspired by the way this word has been used to understand the causes ('drivers') of deforestation. The attribution between outcome and driver is less stringent, since there can be multiple drivers operating at the same time, each pushing a system and each other to a given direction at different levels. The relative strengths of these multiple drivers determine the extent and direction of change within the system (Jacobs et al. 2017). Unless noted otherwise, this term is used in the positive sense, in that drivers of transformational change are conditions and forces that encourage the desired change. In the short term, drivers tend to be exogenous to (i.e. beyond the control of) the actors and actions that strive to create transformational change.

Examples of drivers identified in the scientific literature (see Annex 4):

- UNFCCC negotiations and agreements, particularly NDCs and the Paris Agreement.

- Global debate on climate finance, REDD+ and REDD+ results-based payments.

- Improved resources for advocacy.

- Policy and media engaging dominant actors on how to reduce pressure on forests.

- Government enhancement on policies and measures based on past failures and successes.

- Supportive structures in the country serving (e.g. law, policies) to increase the likelihood that innovation and success cases are scaled up;

- Closer interaction among sectors, including linking natural resource stewards to boost 
environmentally friendly practices in agriculture and livestock.

- Development of alliances and networks for learning and co-operation.

Barriers are the forces opposing change that may prevent the direction, intensity or duration of events from changing. They can be groups of actors with interest in maintaining the status quo, technologies that are locked into existing production and economic systems (e.g. reliance on fossil fuels), incongruence in several related but uncoordinated parts of a system that need to be disentangled prior to embarking in change (e.g. land vs. forest laws), missing technology, funding, knowledge or other capacity deficits, and belief systems. Barriers are the opposite of triggers and drivers.

\section{Examples of barriers (see Annex 4):}

- Little attention and consideration from decision makers in the land-use sector and in land-use planning to the drivers of deforestation and forest degradation.

- Disparities and fragmentation of interests in the broader land-use sector.

- Difficulty reconciling accountability and an open-ended/participatory approach.

Lock-in is "a mode that the system does not easily get out of again due to self-stabilizing feedback" (Scheffer and Westley 2007). It is a kind of barrier, as it prevents systems from shifting in the face of drivers of change. Examples include deforested areas that cannot be restored because the topsoil is lost after the trees are removed. A more elaborate definition is provided in Annex 6 (Glossary).

The Glossary (Annex 6) includes the above and several other concepts that are often used in the transformational change literature, like human agency, paradigm shift and triggers.

\subsubsection{Identifying drivers of transformational change}

Several of the 22 analyzed land-use and climate change-related articles identified drivers and barriers to transformational change (summarized in Annex 4). We analyzed these studies and coded text identifying particular factors that authors suggest could bring about those outcomes. Some drivers were identified through empirical research, while others were part of the authors' hypotheses.
None of the identified drivers have been through rigorous impact evaluation methods. This should not reduce the value of the results, since existing impact evaluation methods are well-suited to simple interventions in simple systems, but new approaches need to be developed to evaluate complex interventions in complex systems (Shiell et al. 2008).

Factors that could drive transformational change are classified into endogenous and exogenous, and barriers. Barriers can also be endogenous or exogenous, although we do not distinguish among them due to limited data. Note that within the same case study, multiple drivers co-exist and can diminish, strengthen or transform each other. For example, international climate finance commitment can drive change, since it affirms national climate change action. Nevertheless, if the global debates are based on norms that do not view national actors as equal partners (e.g. donorrecipient relationship), this could drive low country ownership over global climate change concerns, and possible backlash. Interactions and feedbacks between drivers make it difficult to predict the general direction of change. Nevertheless, our analysis seeks to show which driver can help achieve transformational change if viewed in isolation.

Four groups of drivers were identified from this analysis. Each group can have exogenous and endogenous elements, depending on the context:

1. Resources (R): Factors that provide the energy needed to push for change. For example: information/data, knowledgeable people, funds, dedicated people, time, legal frameworks, market structures, institutions, political will.

2. Legitimacy (L): Factors that help change to be accepted by society as an objective that merits allocation of resources. For example: formation of higher-level agenda, shared concern, economic and political interests, shared narratives, shared vision, heightened awareness.

3. Processes (P): Actions that harmonize efforts and values across different levels and actors. For example: forming a shared vision, collective learning, updating strategies and objectives based on evidence, harmonizing processes and incentives with vision, forming a transition arena, linking and developing actors' alliances across different scales and interests, knowledge management, monitoring and evaluation, scaling up. 


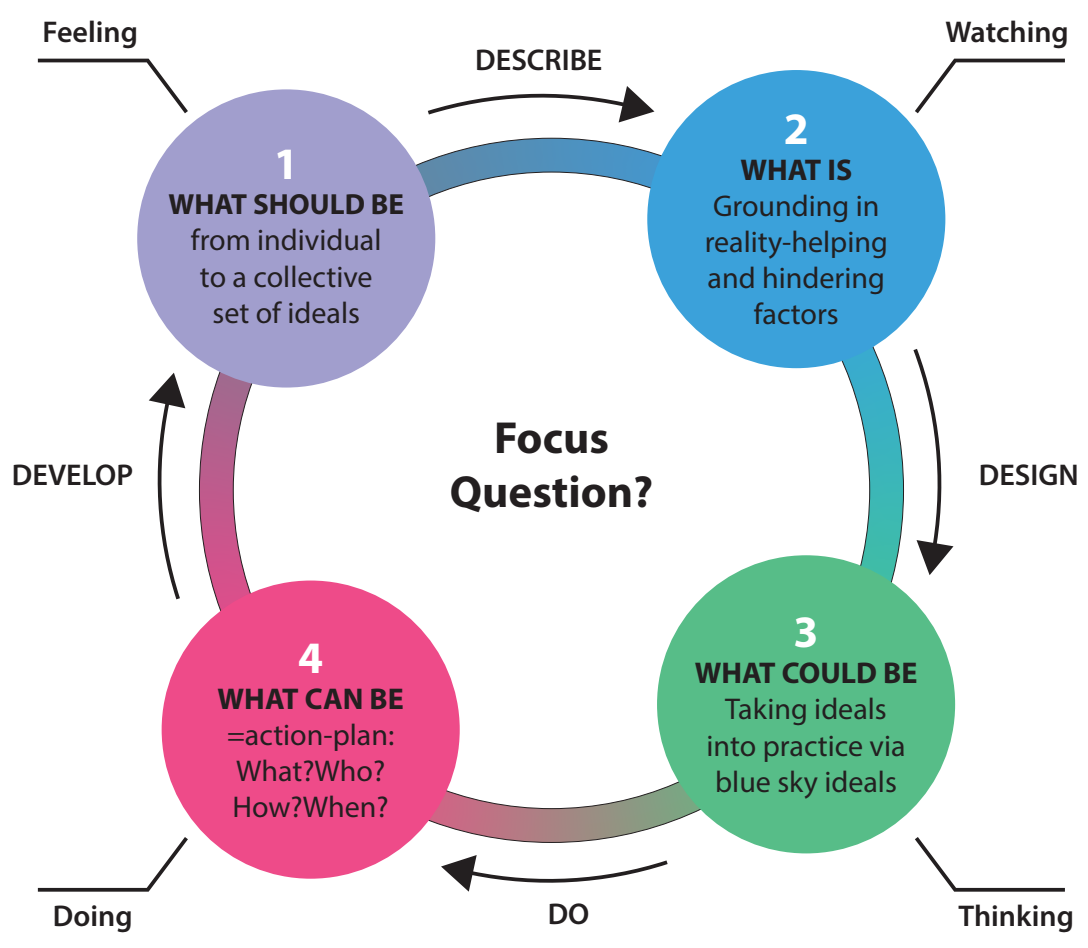

Figure 4. Four stages of the collective social learning cycle.

Source: Brown and Lambert (2015)

4. Norms (N): Values that guide processes to result in sustainable and transformational collaborations. For example: openness to new ideas and actors, equal voice, risk-taking, willingness to empower marginal actors, willingness to learn and share lessons from trial and error, low/no-regrets approach (actions that would be desirable regardless of climate outcomes), a focus that is more on the process.

Authors have diverging opinions on the role of technology and science. Some see them as resources that need to be accessed (Bos et al. 2015), and that generate new lessons and directions. Others see them as a barrier to transformation, when they:

- lead to an undesirable state locking us on an unsustainable path (e.g. Boodoo and Olsen, 2018);

- take away the voice of those who do not have access to them and limit their desire to join the conversation (e.g. Holland, 2017).

This divergence highlights the importance of other drivers (e.g. norms, process, legitimacy), and interactions between drivers that could influence final outcomes.
Learning. Many articles include learning as an essential mechanism to drive transformational change. Brown and Lambert (2015) propose a learning cycle composed of four stages designed to bring about collective social learning and change (Figure 4). Each transformational change has its own context that determines how this cycle is implemented, and whose knowledge and what kind of knowledge can contribute to the learning exercise. This learning cycle has been used at the community level, but can be adapted to other levels.

\subsection{Indicators of transformational change identified in the literature review}

Achieving transformational change requires being able to monitor progress based on specific indicators of success. Here we summarize the indicators used by researchers to monitor and assess transformational change in case studies, grouped by the level of action being monitored or assessed (Annex 5). These indicators were identified in the academic literature that uses a variety of theoretical frameworks. 
Most transformational change indicators in the scientific articles we reviewed are not quantifiable and are difficult to measure, or are not meant to be measured consistently across levels, space and time. The literature focuses on detecting changes in drivers (resources, legitimacy, processes and norms). There are three types of indicators:

1. Level-dependent indicators, aligned to each level's objectives, timeframes, scope, resources and conditions.

2. Level-independent indicators, used for actions at different levels - including processes for learning, participation and decision making and for norms that should be espoused in these various processes.

3. Multi-level indicators, which address how actions at different levels interact and contribute to attaining the desired transformational change, and the norms that the processes relevant for this action should espouse.

Monitoring and impact evaluation are becoming standard practice in most projects, but current monitoring and evaluation practices focus on attaining a pre-determined impact, in adherence to a project or program log frame or theory of change. Impact monitoring tends to focus on level-specific and impact-oriented indicators, while ignoring processes, norms and level-independent and multi-level indicators. For example, theory of change is explicit in identifying 'boundary partners', which are actors that could link projectlevel outputs to higher-level outcomes. It does not normally, in our experience, look at the process and quality of interactions with these boundary partners, something that needs to be done. GCF's Independent Evaluation Unit published a review (Puri, 2018) that asks "What is transformational change? Can we define it? Can we measure it? If a transformational change occurred, would we notice it?" (Puri 2018). The concept of 'measurability' needs to be adapted for the purpose of monitoring transformational change and expanded to include qualitative, non-standardized, non-linear indicators. 


\section{Conclusions}

The This section synthesizes the major insights derived from analyzing the scientific and grey literature (Section 2), and reflects on overarching topics related to human agency, human rights and the role of measurement in transformational change.

\subsection{Highlights and reflections from reviewing the literature}

We offer some highlights from the literature review by focusing on our main questions: (i) What does 'transformational change' mean? and (ii) What drives it?

\subsubsection{What does "transformational change" mean?}

The term 'transformational change' has proliferated in academic literature over the past two decades, mostly in the fields of health, education, public administration and business management. Despite growing interest in this topic, land-use and climate change-specific literature on transformational change still is scarce (just 22 papers found, with the first dating back to 2012), notably in the field of agriculture. The transformational change literature in forestry has so far been restricted to REDD+. Transformational change is better articulated and analyzed in health, education and business management literature, compared to land use and climate change. Some insights on how transformational change manifests in the very long term (e.g. decades and beyond) can be found in the archaeological literature. Interdisciplinary and transdisciplinary learning can be beneficial to understanding transformational change in land use and climate change.

Elements of transformational change definitions have commonalities, differences and tradeoffs. Some definitions differ on whether transformational change is a continuous or discontinuous process, should emphasize process or results, and should focus on large/national scales or multiple scales. This could reflect differences in context, or underlying beliefs on what drives transformational change. In climate change, transformational change is characterized as large, fast and deep change. Termeer et al. (2017) warn that achieving transformational change in all three dimensions at the same time is not possible because of inevitable trade-offs. Defining transformational change objectives and characteristics (i.e. scale, speed and depth) are therefore a central first step for all actors.

Definitions of transformational change often do not explicitly highlight multi-level interactions and interdependencies - in spite of those being a core element in driving and managing transformational change. This reflects the gap between multilevel approaches promoted in the scientific literature, and the top-down approaches espoused by global multilateral institutions. This gap needs to be bridged.

There are fundamental differences in the type of transformations sought, the unit of transformation, the direction of transformation, time scales and expected leader(s) of transformational change. Nevertheless, all disciplines embrace common transformational change objectives, related to change within the context of institutional changes.

Authors writing about transformational change are mostly affiliated to organizations in a handful of developed countries (i.e. Australia, Canada, the United Kingdom and the United States). This may compromise the applicability and acceptability of current transformational change scholarship, since very few organizations (and viewpoints) in other world regions are represented. Nevertheless, scholarship on transformational change within forestry and climate change 
adaptation specifically is relatively new, and has received substantial contributions from researchers based in developing countries (e.g. Brockhaus $e t$ al., 2017; Mapfumo et al. 2017) - a good start that needs to be further encou,raged.

\subsubsection{What drives transformational change?}

Several theoretical frameworks used to analyze transformational change identify similar critical elements for moving towards transformational change. These are:

- collective learning and reflection: learning to inform action, and learning from actions,

- taking and managing risks and expectations: space for innovation, trial and error, and flexibility in program design,

- non-linear thinking that integrates complexity, interconnectedness across multiple dimensions, temporal and spatial scales, and real-time feedback mechanisms,

- consultation and participation: engaging, and consulting with, a wide variety of stakeholders through mechanisms for inclusive, meaningful and enduring participation,

- ownership: e.g. country- or jurisdiction-led approaches; sufficient, flexible and predictable finance.

Development interventions are complex, resulting in a dynamic not completely controlled by any person or institution. Hence, interdisciplinary and transdisciplinary learning and collaboration are required, and it is important for actors to recognize that silver-bullet solutions are rare. It is better to embrace a diversity and multiplicity of approaches.

\section{Four groups of drivers for transformational} change emerged from our literature review: (i) resources: actors that provide the energy needed to push for change; (ii) legitimacy: factors that help change to be accepted by society, as an objective that merits allocation of resources; (iii) processes: actions that harmonize efforts and values across different levels and actors; and (iv) norms: values that guide processes to result in sustainable and transformational collaborations.

Drivers of the transformational change in the land-use sector related to climate change need further exploration and analysis. Transformational change on long-term, multi- decade impacts needs to account for many unpredictable changes in factors that would normally stay static over the short term, like technology, market and policy regimes, demography and ecosystem functions. It is necessary to generate knowledge to support the identification of drivers for achieving transformational change at spatial scales that are unique to the land-use sector and climate change, like landscapes and watersheds; understanding the financial, human and institutional resources needed to sustain transformational change efforts over very long periods; sustaining the momentum and vision of transformational change across political cycles; and institutional measures to facilitate sustained long-term efforts. Nature-based units of transformation (e.g. landscapes, watersheds, ecosystems, biomes) introduce challenges in monitoring and evaluation, multi-level and multisectoral stakeholder coordination, and governance that are unique to land-use and climate change. These could be useful for organizing stakeholder engagement and may better endure political cycles over the long term compared to political units (e.g. cities, jurisdictions). We also acknowledge the crucial role of governing institutions in transformational change (McCall, 2016).

\section{Reflexive actions are the glue that brings} together actions at different levels and time frames, prevents lock-ins and encourages innovation and exploration. Reflexive action (e.g. monitoring, assessments, evaluations) is found in existing institutions (e.g. monitoring and evaluation units, learning forums) or is socially embedded (e.g. media, internet) and needs to be an integrated part of governance processes to be effective. Researchers can play a central role in reflexive action, as researchers analyze longer-term societal processes and dynamics and can put these on the societal and political agenda.

Institutions need to undertake an introspective 'positioning' exercise, where they see themselves as part of a dynamic world of actors that have different interests and competences. Our analysis of transformational change drivers and theoretical frameworks would suggest that such an exercise would help guide partnerships and communication strategies, which are important drivers of transformational change. 


\subsubsection{How is transformational change monitored?}

\begin{abstract}
Indicators of transformational change found in scientific articles have a much wider scope than those used in monitoring and evaluation practices; this gap needs to be bridged.

Indicators in scientific articles monitor changes in drivers of transformational change of all types (resources, legitimacy, processes and norms). They include indicators that are level-dependent (i.e. only applying to outcomes at one level), levelindependent (i.e. applying to outcomes at multiple levels) and multi-level (i.e. applying to interactions across levels). In contrast, monitoring and evaluation practices tend to focus only on leveldependent and impact-oriented indicators, and not on level-independent and multi-level indicators, or on processes and norms.
\end{abstract}

Indicators of transformational change are often unquantifiable, difficult to measure, or not meant to be measured consistently across levels, space and time. This makes it difficult to integrate them into current monitoring and evaluation practices that still focus on measurability. The concept of 'measurability' needs to be adapted for the purpose of monitoring transformational change and expanded to include qualitative, non-standardized, non-linear indicators.

\section{Understanding transformational change in} terms of time requirements is essential for lasting change. Project cycles are either short-term (1, 2 or $3-5$ years) or long-term (5-10 or even 15 years). As speed and urgency are important elements attributed to transformational change by some authors (see Section 2.2.1), it is necessary to understand what kind of transformational change can be expected within these time periods, given the often-ambitious goals and underestimated complexities of policy making. The transition management framework can provide some guidance (see Loorbach, 2010 and Section 2.2.2).

\subsection{Issues for further exploration}

In conducting our literature review, we identified several issues that need to be further explored that were beyond our scope of work. We present them here, in the hope that it will trigger debate and further research.

\subsubsection{Human rights-based approach to transformational change}

A human rights-based approach (HRBA) is defined as:

A conceptual framework for the process of human development that is normatively based on international human rights standards and operationally directed to promoting and protecting human rights (UNDP-HRWG, n.d.).

This approach seeks to analyze inequalities and redress discriminatory practices and unjust distributions, which often impede development progress.

\section{Many of the drivers of transformational change have HRBA elements, despite not being explicitly geared towards promoting and protecting human rights. Many aspects of achieving transformational change are related to addressing inequalities, for example by seeking to ensure wide participation, empowering marginalized groups, correcting injustices and forming a common vision negotiated by all parties. Another transformational change element relevant to HRBA is the right to access information and decision-making processes.}

\section{In striving to achieve transformational change,} some practices may have trade-offs with HRBA. For example, relying on scientific knowledge to define a problem and find solutions may alienate groups who do not have access to that knowledge, limiting their ability to effectively participate in decision-making (Holland, 2017). The quest of transformational change, if narrowly defined in climate change terms, could become a pressure that is externally imposed on developing countries seeking broader development goals (Winkler and Dubash, 2016). Definitions of transformational change emphasize scale, speed and depth of change, which are very difficult to achieve simultaneously (Termeer $e t$ al., 2017). The issues of rights are associated with the depth of change, and could be jeopardized when seeking quick change at scale.

\section{The academic and grey literature on} transformational change has gaps relating to a HRBA. The literature strongly agrees that local ownership in the change process is one of the most important factors of success in transformational change. Yet 'local' means different things, and ranges from national governments to households. 
While the literature emphasizes the significance of providing sufficient resources and incentives to allow stakeholders to undertake transformational change and overcome lock-in, it is less emphatic on the distributional aspects of such provisions. The transformational change literature we reviewed does not provide much guidance on how to design and implement mechanisms to redress discrimination, avoid unjust distribution, and generally ensure human rights are respected and promoted. Mechanisms to manage conflicts were not discussed in detail in the 22 land-use and climate change papers we reviewed. Nevertheless, these mechanisms are important for other factors that have been highlighted as important for transformational change, like attaining legitimacy for the transformations sought, and sustaining dialogue and learning across stakeholders at different levels.

\subsubsection{Human agency to undertake transformational change}

Human agency is the capacity of humans to act in a given environment. The action can be unconscious and involuntary, or purposeful and goal-oriented. The 'how to' literature on transformational change that deals with organizational changes assumes human agency in bringing about transformational change by emphasizing the importance of leadership, political support or cultural/behavioral change (e.g. Brown and Lambert, 2013; Young and Esau, 2016).

There is an important difference in the concept of human agency between literature on land use and climate change and other literature, in viewing humans as the main actors or facilitators of transformational change. This distinction is crucial for interpreting lessons learned from the education and health sectors so they can be applicable for the forestry and agriculture sectors. In land use and climate change, humans facilitate the provision of ecosystem services and products from other entities, like forests, seeds, soils and water bodies. In contrast, health, education and business services are provided by and for humans. For example, environmental and climatic conditions beyond human control have much more influence on agricultural and forestry processes than in education, health and business.

\section{The quest for transformational change in land use and climate change is in itself a result of ongoing transformational change in how}

human beings view their agency over what once was attributed to exogenous entities - like 'God', 'chance' or 'Nature' - or to authoritative figures (see Brown n.d.). From a historical perspective, the assignment of responsibility for global climate change to humans is a new phenomenon, making it hard to understand or believe (Chakrabarty 2012). Humans derive the power to bring about transformational change from the power and responsibility of causing climate change. Although climate change is occurring due to a series of unintended actions, reversing the effects of climate change requires intentional, collective action at a global scale. The sheer effort needed to reverse this problem puts human capacity in doubt. Can 'we' really intervene and shift technologies, practices, social arrangements and their accompanying interdependencies? Some believe, however, that the illusion of such agency is itself important, regardless of how much agency humans actually have. "[I]llusions are productive because they motivate action and repair work, and thus something (whatever) is achieved" (Rip, 2006).

\section{There are two narratives around human agency} in climate change. The adaptation narrative focuses on improving the human ability to adapt to a changing world (Ransan-Cooper, 2016). The story of humans adapting (successfully and unsuccessfully) to various natural and human-made disasters and climatic changes is familiar and easy to understand (Hassan, 2009). Here, the role of human agency is crucial, and not new. The mitigation narrative is inspired by the fighting spirit of humanity, and its new-found perception of power over environmental forces appeals to the notion of mitigating climate change. Yet the narrative of climate change mitigation in land use - and especially forestry — is about facilitating non-human entities, like trees, soils and plants, to sequester or reduce greenhouse gas emissions. Actions to produce greenhouse gas emissions can take much less effort (e.g. cutting down a tree) compared to reversing that emission (e.g. growing a tree). The service rendered (i.e. emission reduction or sequestration) is abstract. Getting public consensus on what to do, and who should do it, is thus even more challenging. As such, the extent of human agency is likely to be higher in the adaptation narrative compared to the mitigation narrative.

\section{The synergies between the adaptation and} mitigation narratives needs to be exploited, while division between the adaptation and mitigation 
narratives highlights the lack of human agency in mitigation, and therefore needs to be avoided. If adaptation is more urgent and compelling in certain contexts (e.g. agriculture drought-prone areas, fisheries in coastal communities), action that has mitigation co-benefits can be prioritized and publicly highlighted. Increasing the frequency and normalcy of mitigation measures, regardless of whether they come about as a by-product of adaptation measures, will reduce the difficulties of introducing predominantly mitigation measures to the public. The opposite is also true. In areas or sectors where climate mitigation values are comparatively easier to understand than its climate adaptation values (e.g. increasing energy efficiency in the transportation sector), its adaptation values need to be highlighted and maximized. Hence, each climate action is a platform to promote the synergies between adaptation and mitigation.

\subsubsection{Developing systems to monitor and measure transformational change}

There is debate on the role and approach of measurements in efforts to bring about transformational change. Some view measurability as an important validator of transformation and as essential to bringing about change. The assumption is that change must be measurable so that it can be monitored and validated, as in Puri's questions: "What is transformational change? Can we define it? Can we measure it? If a transformational change occurred, would we notice it?” (Puri, 2018).

\section{An alternative 'big picture' view needs to be used, where indicators of systemic change are more important than measurement.}

Transformational change is a dynamic process, where change only happens if processes leading to a desired outcome remain in motion (Mapfumo et al. 2017). Within this motion, impacts can be measured; but there is also the need to take a step back and see whether the entire system and all its parts are moving in the right direction. It is possible that, for example, if one part of the system is not changing fast enough to qualify as transformation but other parts are, the entire system is - as a whole - moving forward.

In practice, the 'big picture' approach to measurement is not done often. Most stakeholders are only responsible or concerned with one moving part and in showing how their particular part will be transformational, rather than considering how it fits into the whole system. Or, they are preoccupied with funding particular activities that have the highest likelihood of being transformational. The result is that there is a lack of attention on the larger system or landscape in which these activities are embedded, and thus the transformational process lacks the support and monitoring it needs. Synergies that can catalyze transformational change - or trade-offs that may critically endanger progress - may be overlooked. Yet, taking a big-picture view can also be timeconsuming, challenging, or costly for individuals or organizations. 


\section{References}

350.org. 2019. Global Climate Strike $\rightarrow$ Sep. 20-27. Accessed 1 October 2019. https:// globalclimatestrike.net/.

$\mathrm{Al}$ Jazeera. 15 March 2019. Young people across globe protest against climate change inaction. Al Jazeera. https://www.aljazeera.com/ news/2019/03/young-people-globe-protestclimate-change-inaction-190315114657681. html.

Amansure R and Adendorff C. 2018. Successful transformational change in revenue management among beneficiary communities of South African renewable energy construction companies. Acta Structilia 25(1):71-97. doi:10.18820/24150487/ as $25 \mathrm{i} 1.3$

Ananthakrishnan N, Arora NK, Chandy G, Gitanjali B, Sood R, Supe A and Nagarajan S. 2012. Is there need for a transformational change to overcome the current problems with postgraduate medical education in India? National Medical Journal of India 25(2):101108.

Babon A, McIntyre D, Gowae GY, Gallemore C, Carmenta R, Di Gregorio $M$ and Brockhaus M. 2014. Advocacy coalitions, REDD+, and forest governance in Papua New Guinea: How likely is transformational change? Ecology and Society 19(3). doi:10.5751/es-06486-190316

Bäckstrand K and Lövbrand E. 2016. The road to Paris: Contending climate governance discourses in the post-Copenhagen era. Journal of Environmental Policy and Planning 21(5):519-532. doi:10.1080/152390 $8 x .2016 .1150777$

Biermann F, Abbott K, Andresen S, Bäckstrand K, Bernstein S, Betsill MM, Bulkeley $\mathrm{H}$, Cashore B, Clapp J, Folke J, et al. 2012. Transforming governance and institutions for global sustainability: Key insights from the Earth System Governance Project. Current Opinion in Environmental Sustainability 4(1):51-60. doi:10.1016/j.cosust.2012.01.014
Bird N, Cao Y and Quevedo A. 2019. Transformational change in the Climate Investment Funds: A Synthesis of the evidence. ODI. https://www.odi.org/sites/odi.org.uk/ files/resource-documents/12587.pdf.

Boodoo Z, Mersmann F and Olsen KH. 2018. The implications of how climate funds conceptualize transformational change in developing countries. Climate and Development 10(8):673-686. doi:10.1080/175 65529.2018.1442788

Boodoo Z and Olsen KH. 2018. Assessing transformational change potential: The case of the Tunisian cement Nationally Appropriate Mitigation Action (NAMA). Climate Policy 18(6):794-812. doi:10.1080/14693062.2017. 1386081

Boone J. 2015. Leading learning organizations through transformational change: Making the case for blended learning. International Journal of Educational Management 29(3):275-283. doi:10.1108/ijem-06-2013-0096

Bos JJ, Brown RR and Farrelly MA. 2015. Building networks and coalitions to promote transformational change: Insights from an Australian urban water planning case study. Environmental Innovation and Societal Transitions 15:11-25. doi:10.1016/j. eist.2014.10.002

Brockhaus $M$ and Angelsen A. 2012. Seeing REDD+ through 4Is: A political economy framework. In Angelsen A, Brockhaus M, Sunderlin WD and Verchot L, eds. Analysing REDD+: Challenges and choices. Bogor, Indonesia: CIFOR. 15-30.

Brockhaus M and Di Gregorio M. 2014. National REDD+ policy networks: From cooperation to conflict. Ecology and Society 19(4). doi:10.5751/es-06643-190414

Brockhaus M, Di Gregorio M and Carmenta R. 2014a. REDD+ policy networks: Exploring actors and power structures in an emerging policy domain. Ecology and Society 19(4). doi:10.5751/es-07098-190429 
Brockhaus M, Di Gregorio M and Mardiah S. 2014b. Governing, the design of national REDD+: An analysis of the power of agency. Forest Policy and Economics 49, 23-33. doi:10.1016/j.forpol.2013.07.003

Brockhaus M, Korhonen-Kurki K, Sehring J, Di Gregorio M, Assembe-Mvondo S, Babon A, Bekele M, Gebara MF, Khatri DB, Kambire $\mathrm{H}$, et al. 2017. REDD+, transformational change and the promise of performance-based payments: A qualitative comparative analysis. Climate Policy 17(6):708-730.

Brown V. n.d. What is transformational change? Accessed 28 January 2019.

http://www.collectivethinking.com.au/keyissues/transformational-change/what-istransformational-change/

Brown V and Lambert J. 2015. Transformational learning: Are we all playing the same 'game'? Journal of Transformative Learning 3(1):35-41.

Brown VA and Harris JA. 2014. The human capacity for transformational change: Harnessing the collective mind. Routledge.

Brown VA and Lambert JA. 2013. Collective learning for transformational change: A guide to collaborative action. New York, NY: Routledge.

Chakrabarty D. 2012. Postcolonial studies and the challenge of climate change. New Literary History 43(1):1-18. doi:10.1353/ nlh.2012.0007

Chapin FS 3rd, Zavaleta ES, Eviner VT, Naylor RL, Vitousek PM, Reynolds HL, Hooper DU, Lavorel S, Sala OE, Hobbie SE, Mack MC and Diaz S. 2000. Consequences of changing biodiversity. Nature 405(6783):234-242. doi:10.1038/35012241

Chia EL, Hubert D, Carudenuto $S$ and Sene O. 2019. Evolution in the enabling factors for transformational change in forestry and land use policy processes: The case of REDD+ in Cameroon. International Forestry Review 21(1):62-72. doi:10.1505/146554819825863762

[CIF and Itad] Climate Investment Funds and Itad. 2020. Signals of transformational change: Insights from the evaluation of transformational change in the Climate Investment Funds. https://www.climateinvestmentfunds.org/ sites/cif_enc/files/knowledge-documents/ tc_signals_brief.pdf.

[CIFOR] Center for International Forestry Research. 2020. Policy network analysis: Actors and power structures. Accessed 15 September 2020. https://www2.cifor.org/gcs/modules/ redd-policies/policy-network-analysis-actorspower-structures/

[CIPD] Chartered Institute of Personnel and Development. 2015. Landing transformational change: Closing the gap between theory and practice. London: CIPD. https://www.cipd. co.uk/Images/landing-transformationchange_2015-gap-theory-practice_tcm 18 9050.pdf.

Cornell S, Berkhout F, Tuinstra W, Tàbara JD, Jäger J, Chabay I, de Wit B, Langlais R, Mills D, Moll P and Otto IM. 2013. Opening up knowledge systems for better responses to global environmental change. Environmental Science and Policy 28(Apr 1):60-70.

Derner JD, Smart AJ, Toombs TP, Larsen D, McCulley RL, Goodwin J, Sims S and Roche LM. 2018. Soil health as a transformational change agent for US grazing lands management. Rangeland Ecology and Management 71(4):403-408. doi:10.1016/j. rama.2018.03.007

Di Gregorio M, Brockhaus M, Cronin T, Muharrom E, Mardiah S and Santoso L. 2015. Deadlock or transformational change? Exploring public discourse on REDD+ across seven countries. Global Environmental Politics 15(4):63-84. doi:10.1162/GLEP_a_00322

Dinerstein E, Vynne C, Sala E, Joshi AR, Fernando S, Lovejoy TE, Mayorga J, Olson D, Asner GP, Baillie JEM, Burgess ND, Burkart K, Noss RF, Zhang YP, Baccini A, Birch T, Hahn N, Joppa LN and Wikramanayake E. 2019. A Global Deal For Nature: Guiding principles, milestones, and targets. Scientific Advances 5(4):eaaw2869. doi:10.1126/sciadv.aaw2869

Douthwaite MB. 2002. Enabling innovation: A practical guide to understanding and fostering technological change. Zed Books.

Durie R and Wyatt K. 2013. Connecting communities and complexity: A case study in creating the conditions for transformational change. Critical Public Health 23(2):174-187. doi:10.1080/09581596.2013.781266

[EC] European Commission. n.d. A European Green Deal. Accessed 19 March 2021. https://ec.europa.eu/info/strategy/ priorities-2019-2024/european-green-deal_en

[FAO] Food and Agriculture Organization of the United Nations. 2019. Policy Support and Governance. Accessed 1 October 2019. http:// www.fao.org/policy-support/vision/en/

Forsell N, Turkovska O, Gusti M, Obersteiner M, Elzen MD and Havlik P. 2016. Assessing the 
INDC's land use, land use change and forest emission projections. Carbon Balance and Management 11(1):26. doi:10.1186/s13021016-0068-3

Fridahl M and Johansson L. 2017. An assessment of the potential for spurring transformational change through Nationally Appropriate Mitigation Actions (NAMAs). Environmental Innovation and Societal Transitions 25:35-46. doi:10.1016/j.eist.2016.11.003

Fridays for Future. n.d. Accessed 19 March 2021. https://www.fridaysforfuture.org/

[GCF] Green Climate Fund. 2018a. Investment Criteria Indicators. GCF/B.20/Inf.14. Songdo, Republic of Korea: Green Climate Fund. https://www.greenclimate. fund/documents/20182/1087995/ GCF_B.20_Inf.14_-_Investment_criteria_ indicators.pdf/69363c9f-c893-0fc7-953bd75504bd4870.

[GCF] Green Climate Fund. 2018b. Results management framework: Independent Evaluation Unit recommendations to improve the Results Management Framework. GCF/B.21/20. Incheon, Republic of Korea: Green Climate Fund. https://www.greenclimate. fund/documents/20182/1270184/ GCF_B.21_20_-_Results_management_ framework_Independent_Evaluation_Unit_ recommendations_to_improve_the_Results_ Management_Framework___Final_Report. pdf/17a4ccbb-b891-53bf-55b1b4d4c8a7a734.

[GCF] Green Climate Fund. 2016. Initial strategic plan for the GCF. Sondo, South Korea: Green Climate Fund. https://www.greenclimate. fund/documents/20182/761223/Initial_ Strategic_Plan_for_the_GCF.pdf/bb18820eabf0-426f-9d8b-27f5bc6fafeb.

Geels FW. 2002. Technological transitions as evolutionary reconfiguration processes: A multi-level perspective and a casestudy. Research Policy 31:1257-1274.

GIZ. 2020. Transforming our work: Getting ready for transformational projects. Eschborn, Germany: GIZ. https://www.giz.de/ fachexpertise/downloads/Transfomation $\% 20$ Guidance_GIZ_02\%202020.pdf.

Glover A and Schroeder H. 2017. Legitimacy in REDD+ governance in Indonesia. International Environmental Agreements: Politics, Law and Economics 17(5):695-708. doi:10.1007/s10784-016-9341-x
Grassi G, House J, Dentener F, Federici S, den Elzen M and Penman J. 2017. The key role of forests in meeting climate targets requires science for credible mitigation. Nature Climate Change 7(3):220-226. doi:10.1038/ nclimate3227

Griscom BW, Busch J, Cook-Patton SC, Ellis PW, Funk J, Leavitt SM, Lomax G, Turner WR, Chapman M, Engelmann J, et al. 2020. National mitigation potential from natural climate solutions in the tropics. Philosophical Transactions of the Royal Society B 375(1794):20190126. doi:10.1098/ rstb.2019.0126

Griscom BW, Adams J, Ellis PW, Houghton RA, Lomax G, Miteva DA, Schlesinger WH, Shoch D, Siikamaki JV, Smith P, et al. 2017. Natural climate solutions. Proceedings of the National Academy of Sciences of the United States of America 114(44):11645-11650. doi:10.1073/pnas.1710465114

Gunderson L and Folke C. 2011. Resilience 2011: Leading Transformational Change. Ecology and Society, 16(2).

Hassan FA. 2009. Human agency, climate change, and culture: An archaeological perspective. In Crate SA and Nuttall M, eds. Anthropology and climate change: From encounters to actions. Walnut Creek, CA: Left Coast Press. 39-69.

Hawkins J. 2018. Transformational change in environmental and natural resource management: A guideline for policy excellence. Australian Journal of Agricultural and Resource Economics 62(3):501-503.

Holland B. 2017. Procedural justice in local climate adaptation: political capabilities and transformational change. Environmental Politics 26(3):391-412. doi:10.1080/0964401 6.2017 .1287625

[IPCC] Intergovernmental Panel on Climate Change. 2019. Climate Change and Land: An IPCC Special Report on Climate Change, Desertification, Land Degradation, Sustainable Land Management, Food Security and Greenhouse Gas fluxes in Terrestrial Ecosystems. Summary for Policymakers. Approved Draft. IPCC. IPCC] Intergovernmental Panel on Climate Change. 2018a. Global Warming of 1.5 Degrees - Technical Summary. WMO, UNEP.

[IPCC] Intergovernmental Panel on Climate Change. 2018b. IPCC, 2018: Summary for Policymakers. In Masson-Delmotte V, Zhai P, Pörtner H-O, Roberts D, Skea J, Shukla 
PR, Pirani A, Moufouma-Okia W, Péan C, Pidcock R, et al. eds. Global Warming of $1.5^{\circ} \mathrm{C}$. An IPCC Special Report on the impacts of global warming of $1.5^{\circ} \mathrm{C}$ above pre-industrial levels and related global greenhouse gas emission pathways, in the context of strengthening the global response to the threat of climate change, sustainable development and efforts to eradicate poverty. Geneva, Switzerland: World Meteorological Organization. 32.

https:/www.ipcc.ch/site/assets/ uploads/2019/08/4.-SPM_Approved_ Microsite_FINAL.pdf.

[IPCC] Intergovernmental Panel on Climate Change. 2012. Managing the Risks of Extreme Events and Disasters to Advance Climate Change Adaptation. Cambridge: Cambridge University Press.

Itad. 2019. Evaluation of Transformational Change in the Climate Investment Funds. https://www. climateinvestmentfunds.org/sites/cif_encl files/knowledge-documents/evaluation_of_ transformational_change_in_the_cif_final_w_ mresp_jan_2019.pdf

Jacobs B, Cordell D, Chin J and Rowe H. 2017. Towards phosphorus sustainability in North America: A model for transformational change. Environmental Science and Policy 77:151-159. doi:10.1016/j. envsci.2017.08.009

Kezar A. 2013. Understanding sensemaking/ sensegiving in transformational change processes from the bottom up. Higher Education 65(6):761-780. doi:10.1007/ s10734-012-9575-7

Kezar A and Eckel P. 2002. Examining the institutional transformation process: The importance of sensemaking, interrelated strategies and balance. Research in Higher Education 43(3):295-328. doi:10.1023/a:1014889001242

Klein N. 2015. This changes everything: Capitalism $v s$. the climate. Simon and Schuster.

Korhonen-Kurki K, Brockhaus M, Sehring J, Di Gregorio M, Assembe-Mvondo S, Babon A, Bekele M, Benn V, Gebara MF, Kambire HW, et al. 2019. What drives policy change for REDD+? A qualitative comparative analysis of the interplay between institutional and policy arena factors. Climate Policy 19(3):315-328. doi:10.1080/14693062.2018.1507897

Korhonen-Kurki K, Sehring J, Brockhaus M and Di Gregorio M. 2014. Enabling factors for establishing REDD plus in a context of weak governance. Climate Policy 14(2):167-186. doi :10.1080/14693062.2014.852022

Le Quéré C, Andrew RM, Friedlingstein P, Sitch S, Hauck J, Pongratz J, Pickers PA, Korsbakken JI, Peters GP, Canadell JG et al. 2018. Global Carbon Budget 2018. Earth System Science Data 10(4):2141-2194. doi:10.5194/essd-102141-2018

Loorbach D. 2010. Transition management for sustainable development: A prescriptive, complexity-based governance framework. Governance 23(1):161-183. doi:10.1111/ j.1468-0491.2009.01471.x

Mapfumo P, Onyango M, Honkponou SK, El Mzouri EH, Githeko A, Rabeharisoa L, Obando J, Omolo N, Majule A, Denton F, Ayers J and Agrawal A. 2017. Pathways to transformational change in the face of climate impacts: An analytical framework. Climate and Development 9(5):439-451. doi:10.1080/1756 5529.2015.1040365

Markard J, Raven R and Truffer B. 2012. Sustainability transitions: An emerging field of research and its prospects. Research Policy 41(6):955-967.

Martius C, Angelsen A, Larson AM, Pham TT, Sonwa DJ and Belcher B. 2018. Pathway to impact. Is REDD+ a viable theory of change? In Angelsen A, Martius C, Duchelle AE, Larson AM, de Sy V and Pham TT eds. Transforming REDD+. Bogor, Indonesia: CIFOR.

McAlpine CA, Seabrook LM, Ryan JG, Feeney BJ, Ripple WJ, Ehrlich AH and Ehrlich PR. 2015. Transformational change: Creating a safe operating space for humanity. Ecology and Society 20(1). doi:10.5751/es-07181-200156

McCall MK. 2016. Beyond 'landscape' in REDD+: The imperative for 'territory'. World Development 85(September):58-72.

Mersmann F and Wehnert T. 2015. Governance and Action: Design Criteria for Transformational Climate Finance. Berlin, Germany: Wuppertal Institute for Climate, Environment and Energy GmbH. https://wupperinst.org/ uploads/tx_wupperinst/Governance_Action. pdf.

Mersmann F, Wehnert T, Gopel M, Arens S and Ujj O. 2014. Shifting Paradigms: Unpacking Transformation for Climate Action. A Guidebook for Climate Finance and Development Practitioners. Wuppertal Institute for Climate, Environment and Energy GmbH. https://epub.wupperinst.org/frontdoor/ 
deliver/index/docId/5518/file/5518_Shifting_ Paradigms.pdf.

Moeliono M, Gallemore C, Santoso L, Brockhaus $M$ and Di Gregorio M. 2014. Information networks and power: Confronting the 'wicked problem' of REDD plus in Indonesia. Ecology and Society 19(2). doi:10.5751/es-06300190209

Moeliono, M., Brockhaus, M., Gallemore, C., Dwisatrio, B., Maharani, C. D., Muharrom, E., \& Pham, T. T. (2020). REDD+ in Indonesia: A new mode of governance or just another project?. Forest Policy and Economics, 121: 102316. doi:10.1016/j. forpol.2020.102316

Myers R, Larson AM, Ravikumar A, Kowler LF, Yang A and Trench T. 2018. Messiness of forest governance: How technical approaches suppress politics in REDD+ and conservation projects. Global Environmental Change 50:314324. doi:10.1016/j.gloenvcha.2018.02.015

Nam K, Oh SW, Kim SK, Goo J and Khan MS. 2016. Dynamics of enterprise architecture in the Korean public sector: Transformational change vs. transactional change. Sustainability 8(11):18. doi:10.3390/su8111074

Ngendakumana S, Minang PA, Feudjio M, Speelman S, Van Damme P and Tchoundjeu Z. 2014. Institutional dimensions of the developing REDD+ process in Cameroon. Climate Policy, 14(6):769-787. doi:10.1080/14 693062.2014.877221

Pagoropoulos A, Maier A and McAloone TC. 2017. Assessing transformational change from institutionalising digital capabilities on implementation and development of Product-Service Systems: Learnings from the maritime industry. Journal of Cleaner Production 166:369-380. doi:10.1016/j. jclepro.2017.08.019

Puri J. 2018. Transformational Change - The Challenge of a Brave New World. Independent Evaluation Unit Working Paper No. 001. Songdo, South Korea: Green Climate Fund.

Ransan-Cooper H. 2016. The role of human agency in environmental change and mobility: A case study of environmental migration in Southeast Philippines. Environmental Sociology 2(2): 132-143. doi:10.1080/23251042.2016. 1144405

Reynolds JF, Smith DM, Lambin EF, Turner BL 2nd, Mortimore M, Batterbury SP, Downing TE, Dowlatabadi H, Fernandez RJ, Herrick JE et al. 2007. Global desertification:
Building a science for dryland development. Science 316(5826):847-851. doi:10.1126/ science. 1131634

Rip A. 2006. A co-evolutionary approach to reflexive governance - and its ironies. In Voss J-P Bauknecht D and Kemp R eds. Reflexive Governance for Sustainable Development. Cheltenham, UK: Edward Elgar.

Rip A and Kemp R. 1998. Technological change. In Rayner $S$ and Malone EL, eds. Human Choice and Climate Change (Vol. 2). Columbus, OH: Battelle Press. 327-399

Rogelj J, Popp A, Calvin KV, Luderer G, Emmerling J, Gernaat D, Fujimori S, Strefler J, Hasegawa T, Marangoni G et al. 2018. Scenarios towards limiting global mean temperature increase below $1.5^{\circ} \mathrm{C}$. Nature Climate Change 8(4):325-332. doi:10.1038/ s41558-018-0091-3

Ross H. 2013. Collective learning for transformational change: A guide to collaborative action. Australasian Journal of Environmental Management 20(3):257-259. do i: $10.1080 / 14486563.2013 .826121$

Rotmans J, Kemp R and van Asselt M. 2001. More evolution than revolution: Transition management in public policy. Foresight 3(1):15-31. doi:10.1108/14636680110803003

Sanz MJ, De Vente JL, Chotte JL, Bernoux M, Kust G, Ruiz I, Almagro M, Alloza JA, Vallejo R, Castillo V and Hebel A. 2017. Sustainable Land Management contribution to successful landbased climate change adaptation and mitigation: A report of the science-policy interface. Bonn, Germany: UNCCD. http:// horizon.documentation.ird.fr/exl-doc/pleins textes/divers17-11/010071102.pdf.

Scheffer M and Westley FR. 2007. The evolutionary basis of rigidity: Locks in cells, minds and society. Ecology and Society 12(2):36.

Schindler DE and Hilborn R. 2015. Sustainability: Prediction, precaution and policy under global change. Science 347(6225):953-954. doi:10.1126/science.1261824

Schoon M, Fabricius C, Anderies JM and Nelson M. 2011. Synthesis: vulnerability, traps, and transformations-long-term perspectives from archaeology. Ecology and Society 16(2):24.

Scott SM. 2017. Collective learning for transformational change: A guide to collaborative action. Journal of 
Transformative Education 15(1):95-97. doi:10.1177/1541344616629792

Shiell A Hawe P and Gold L. 2008. Complex interventions or complex systems? Implications for health economic evaluation. BMJ 336(7656):1281-1283. doi:10.1136/ bmj.39569.510521.AD

Shove E and Walker G. 2016. Caution! Transitions ahead: Politics, practice and sustainable transition management. Environment and Planning A: Economy and Space 39(4):763770. doi:10.1068/a39310

Termeer C, Dewulf A and Biesbroek GR. 2017. Transformational change: governance interventions for climate change adaptation from a continuous change perspective. Journal of Environmental Planning and Management 60(4):558-576. doi:10.1080/09640568.2016. 1168288

Totin E, Butler JR, Sidibe A, Partey S, Thornton PK and Tabo R. 2018. Can scenario planning catalyse transformational change? Evaluating a climate change policy case study in Mali. Futures 96: 44-56. doi:10.1016/j. futures.2017.11.005

Tubiello FN, Salvatore M, Ferrara AF, House J, Federici S, Rossi S, Biancalani R, Condor Golec RD, Jacobs H, Flammini A, et al. 2015. The contribution of agriculture, forestry and other land use activities to global warming, 1990-2012. Global Change Biology 21(7):2655-2660. doi:10.1111/gcb.12865

[UNDP] United Nations Development Programme. 2011. Case Studies of Sustained and Successulf Development Cooperation: Supporting Transformational Change. United Nations Development Programme. http:// www.undp.org/content/dam/undp/library/ Cross-Practice\%20generic\%20theme/ Supporting-Transformational-Change.pdf. [UNDP-HRWG] United Nations Development Programme Human Rights Working Group. (n.d.). What is a human rights-based approach? Accessed 8 April 2019. https://hrbaportal.org/ faq/what-is-a-human-rights-based-approach.

[UNEP] United Nations Environment Programme. 2019. Emissions Gap Report 2019. Nairobi: United Nations Environment Programme. http://www.unenvironment.org/ emissionsgap.

Wallace-Wells D. 2019. The Uninhabitable Earth: Life After Warming. Tim Duggan Books.

Well $\mathrm{M}$ and Carrapatoso A. 2016. REDD+ finance: policy making in the context of fragmented institutions. Climate Policy 17(6):687-707. doi:10.1080/14693062.2016. 1202096

Winkler H and Dubash NK. 2016. Who determines transformational change in development and climate finance? Climate Policy 16(6):783-791. doi:10.1080/14693062. 2015.1033674

Young MD and Esau C, eds. 2016. Transformational Change in Environmental and Natural Resource Management. A Guidelines for Policy Excellence. London and New York: Routledge, Earthscan. 


\section{Glossary}

Barriers are the forces opposing change that may prevent the direction, intensity or duration of events from changing. They can be groups of actors with interest in the status quo, technologies that are locked into existing production and economic systems (e.g. reliance on fossil fuels), incongruence in several related but uncoordinated parts of a system that need to be disentangled prior to embarking in change (e.g. land vs. forest laws), missing technology, funding, knowledge or other capacity deficits, and belief systems. Barriers are the opposite of triggers and drivers.

Business-as-usual: the dominant functioning of the current system (Jacobs et al., 2017).

Drivers are underlying and proximate conditions and the forces that influence the outcome of actions. This definition is inspired by the way this word has been used to understand the causes ('drivers') of deforestation. The attribution between outcome and driver is less stringent, since there can be multiple drivers operating at the same time, each pushing a system and each other to a given direction at different levels. The relative strengths of these multiple drivers determine the extent and direction of change within the system (Jacobs et al. 2017). Unless noted otherwise, this term is used in the positive sense, in that drivers of transformational change are conditions and forces that encourage the desired change. In the short term, drivers tend to be exogenous to (i.e. beyond the control of) the actors and actions that strive to create transformational change.

Human agency is the capacity of humans to act in a given environment. The action can be unconscious and involuntary, or purposeful and goal-oriented.

Lock-in is a state that a system "does not easily get out of again due to self-stabilizing feedback" (Scheffer and Westley, 2007) because some kind of barrier it prevents systems from shifting in the face of triggers of change. Getting public consensus from a vast group of people (e.g. the world's citizens) to move to a new, less emitting and more resilient state is exceptionally challenging. Psychologically, groups of people tend to lock into attitudes, despite given ample information that something urgent needs to be done. Individuals, who would have acted if alone, instead decide whether to act based on others' (in)action. The result is that groups tend to be more conservative and less likely to respond compared to individuals; in times of crisis, groups tend to be even more rigid and to adhere to old structures and habits (e.g. traditions, values) (Scheffer and Westley, 2007). Attempts to bring about transformational change by using pre-existing and win-win solutions and engaging only with dominant actors in a given sector, for example, can lead to strengthening existing conditions and lead to lock-in rather than transformational change (e.g. Boodoo and Olsen, 2018).

Paradigm shift is the accumulation of anomalies in data collected using one perspective or set of assumptions, resulting in a sudden and radical shift in perspectives and a new theory that 'explains' the anomalies (Scheffer and Westley, 2007). It is a change in approach, underlying assumptions, philosophy or world view, with explicitly different - and possibly opposite - components compared to the current one.

Transformational change is defined differently according to context, and has the following common features:

- Movement away from the current regime, equilibrium or business-as-usual situation, and opening of new pathways 
- Sustained changes, either through institutionalization within systems, or changes in cultures, beliefs and power relations

- Focus on root causes and on relationships between dimensions of change (e.g. organizations, markets, technologies, power and social relations, and ideas), i.e. deep change

- Emphasis on learning, either as a driver or indicator of change.

- Some definitions diverge from each other, for example:

- The idea that transformational change can be achieved through continuous processes and a series of incremental steps (Jacobs et al., 2017; Boodoo and Olsen, 2018) versus the idea that is can be achieved through discontinuous or disruptive processes (Brown n.d.; Mapfumo et al., 2017).

- Emphasis on results of particular actions or investments (UNDP, 2011) versus emphasis on the process (Brown, n.d.; Holland, 2017; Jacobs et al., 2017; Mapfumo et al., 2017)

- Emphasis on national or large-scale change (UNDP, 2011; CIPD, 2015; GCF, 2016; GEF, 2018; FAO, 2019) versus emphasis on changes across scales (Brown, n.d.; Jacobs et al., 2017).

Transformational reform is a change in strategy, with consequences for how organizations are structured, for resource use, and for individual behavior (Young and Esau, 2016).

Transition is a "substantial change and movement from one state to another" (Shove and Walker, 2016); "a set of connected changes, which reinforce each other but take place in several different areas, like technology, the economy, institutions, behavior, culture, ecology and belief systems. A transition can be seen as a spiral that reinforces itself; there are multiple causality and co-evolution caused by independent developments" (Rotmans et al., 2001). These changes happen at varying scales and speeds (Jacobs et al., 2017).

Transition pathways result from the adoption of innovative technologies and practices that deviate from business-as-usual (Jacobs et al., 2017). Such pathways can take place in different areas (e.g. technology, society, ecology, human behavior, beliefs) and can reinforce each other. A 'successful' pathway is enabled through "path constitution, the interplay of innovative technology, human agency and mindful decision making" (Jacobs et al., 2017).

Triggers for change are short-term events that cause a shift to a new equilibrium in a system. These events open spaces for innovation to create alternative regimes (Loorbach, 2010).

Exogenous triggers come from outside the system. These triggers include armed conflict, disease epidemics, natural disasters, financial crises or regime changes (UNDP, 2011). It may not be possible or ethical to create external triggers, yet it is possible to time interventions to take advantage of triggers to bring about the desired transformational change.

Endogenous triggers are part of the system to be transformed, although they may be outside of the scope of a particular activity, project or program within the system. They can be brought about by an active transitions arena, or a defined group of actors who can identify synergies and bring together actors, lessons and resources to evolve towards the desired goal. These triggers add pressure for change led by transformational leaders, or what the REDD+ literature refers to as "transformational coalitions" (Babon et al., 2014; Brockhaus et al., 2014a, 2017; Moeliono et al., 2014). When change is urgently needed, individual leaders or coalitions are critical in starting or hindering movements towards change. The importance of leaders is seen in the transformational change literature's focus on guiding leaders through the steps of bringing their organizations through change (e.g. 'change management'), or creating conditions to encourage supportive coalitions to form (e.g. through dialogue, collective learning processes). 


\section{Annexes}

\section{Annex 1. Method used to select academic literature for review}

To capture the latest in theoretical and analytical thinking on transformational change, we applied specific search protocols to explore the Web of Science scientific literature database, limiting our search to full-length articles published between January 2000 and September 2018, including papers submitted to conferences.

1. Level 1 analysis: Articles with 'transformational change' in the title (TI)

- $\mathrm{TI}=$ 'transformational change'

- Timespan: 2000-2018. Indexes: SCI-EXPANDED, SSCI, AandHCI, ESCI

This resulted in 113 publications. Two publications were removed: (i) One publication was deleted because Web of Science erroneously listed a publication with a different title than was listed in the database, and the title did not match our search parameters (Well and Carrapatoso, 2016); (i) The other was removed because it was a correction for a publication already included, thereby inflating the information obtained from that publication. The remaining 111 articles underwent Level 1 analysis, where they were scanned for composition by topic, number of authors per article, and country of authorship.

2. Level 2 analysis: publications related to agriculture, forestry or climate change

The 111 publications that were identified in Level 1 analysis were further filtered based on title (TI) and subject $(\mathrm{SU})$ using the following search terms:

- TI='transformational change' AND (SU=(forestry OR agriculture OR ecology) OR TS='climate change')

- Timespan: 2000-2018. Indexes: SCI-EXPANDED, SSCI, AandHCI, ESCI

The filtered results included several publications outside the boundary of forestry and climate change, like urban water management and mining, but which were nevertheless relevant when we take a broader view of land use. This search yielded 23 articles. Two articles (Nam et al., 2016; Pagoropoulos et al., 2017) were dropped because their focus was on transforming the architecture of information technology systems, rather than socio-ecological systems. One editorial in a series of special issues (Gunderson and Folke, 2011) was replaced by a synthesis article within one of the special issues covered in this editorial (Schoon et al., 2011). Three reviews of two books (Ross, 2013; Scott, 2017; Hawkins, 2018) were replaced by the books being reviewed (Brown and Lambert, 2013; Young and Esau, 2016). The final number of articles analyzed was 20 . These 20 articles went through Level 2 analysis to better understand their definition, theoretical framework and drivers of transformational change.

The resulting articles and their replacements are listed in Annex 5.2.

One limitation of this method is that it only includes International Scientific Indexing (ISI) publications, which are mostly journals written in English. It also relies on the use of the term 'transformational change' in the title, which is restrictive. Nevertheless, this represents the 'cutting edge' thoughts and analysis on transformational change. Results from reviewing this body of academic literature were used as the starting point of the theoretical section of this paper. We also included literature cited in these articles, with particular attention to preceding supporting work and articles that heavily influenced the author(s)' conceptualization of transformational change in the land-use and climate change literature. 


\section{Annex 2. List of articles selected for review}

We broke our analyses into two levels - Level 1: transformational change articles from all fields, analyzed for topic, number of authors per article and country of authorship; Level 2: land-use and climate change articles, analyzed for transformational change definition, theoretical framework and drivers. After removals and replacements (see Section 5.1), the final number of articles analyzed was 20.

Table 2. Summary of type, unit, direction and expected leader of transformational change across research areas (based on literature review)

\begin{tabular}{|c|c|c|}
\hline \multirow[t]{2}{*}{ Citation (Publication type) } & \multicolumn{2}{|c|}{ Analysis } \\
\hline & Level 1 & Level 2 \\
\hline $\begin{array}{l}\text { Allen B. 2015. Transformational change for radiology. Health Affairs 34(3):1. } \\
\text { doi:10.1377/hlthaff.2015.0088 (Letter) }\end{array}$ & Yes & No \\
\hline $\begin{array}{l}\text { Amansure R and Adendorff C. } 2018 \text {. Successful transformational change in revenue } \\
\text { management among beneficiary communities of South African renewable energy } \\
\text { construction companies. Acta Structilia 25(1):71-97. doi:10.18820/24150487/as25i1.3 } \\
\text { (Article) }\end{array}$ & Yes & No \\
\hline $\begin{array}{l}\text { Ananthakrishnan N, Arora NK, Chandy G, Gitanjali B, Sood R, Supe A and } \\
\text { Nagarajan S. 2012. Is there need for a transformational change to overcome the } \\
\text { current problems with postgraduate medical education in India? National Medical } \\
\text { Journal of India 25(2):101-108. (Article) }\end{array}$ & Yes & No \\
\hline
\end{tabular}

\section{[APIC] Association for Professionals in Infection Control and Epidemiology. \\ 2018. APIC's strategic partners: Committed to transformational change. American Journal of Infection Control 46(11):1201-1201. doi:10.1016/j.ajic.2018.09.021 (Editorial Material)} Yes No

\section{[APIC] Association for Professionals in Infection Control and Epidemiology.}

2017. APIC's strategic partners: Committed to transformational change. American Journal of Infection Control 45(12):1297-1297. doi:10.1016/j.ajic.2017.10.010 (Editorial Material)

Aveling W. 2006. Patient-controlled epidural analgesia and transformational change Yes No - Reply. International Journal of Obstetric Anesthesia 15(2):170-170. doi:10.1016/j. ijoa.2005.12.004 (Letter)

Babon A, McIntyre D, Gowae GY, Gallemore C, Carmenta R, Di Gregorio M and
Brockhaus M. 2014. Advocacy coalitions, REDD+, and forest governance in Papua
New Guinea: How likely is transformational change? Ecology and Society 19(3):13.
doi:10.5751/es-06486-190316 (Article)

Balcinovic M. 2014. Achieving transformational change in academic libraries. Yes No Australian Library Journal 63(1):52-52. doi:10.1080/00049670.2013.878265 (Book Review)

Balmer D and Carraccio C. 2015. Innovation in pediatric education: Promoting and undergoing transformational change. Pediatrics 135(3):399-402. doi:10.1542/ peds.2014-2565 (Editorial Material)

Bergh AM, Bac M, Hugo J and Sandars J. 2016. "Making a difference" - Medical students' opportunities for transformational change in health care and learning through quality improvement projects. BMC Medical Education 16:8. doi:10.1186/ s12909-016-0694-1 (Article)

Blantern C. 2015. Dialogic organization development: The theory and practice of Yes No transformational change. Action Learning 12(3):358-366. doi:10.1080/14767333.2015. 1094622 (Book Review) 


\begin{tabular}{|c|c|c|}
\hline \multirow[t]{2}{*}{ Citation (Publication type) } & \multicolumn{2}{|l|}{ Analysis } \\
\hline & Level 1 & Level 2 \\
\hline $\begin{array}{l}\text { Bleijenbergh I. 2018. Transformational change towards gender equality: An } \\
\text { autobiographical reflection on resistance during participatory action research. } \\
\text { Organization 25(1):131-138. doi:10.1177/1350508417726547 (Article) }\end{array}$ & Yes & No \\
\hline $\begin{array}{l}\text { Boodoo Z and Olsen KH. 2018. Assessing transformational change potential: The } \\
\text { case of the Tunisian cement Nationally Appropriate Mitigation Action (NAMA). } \\
\text { Climate Policy 18(6):794-812. doi:10.1080/14693062.2017.1386081 (Article) }\end{array}$ & Yes & Yes \\
\hline $\begin{array}{l}\text { Boodoo Z, Mersmann F and Olsen KH. 2018. The implications of how climate } \\
\text { funds conceptualize transformational change in developing countries. Climate and } \\
\text { Development 10(8):673-686. doi:10.1080/17565529.2018.1442788 (Article) }\end{array}$ & Yes & Yes \\
\hline $\begin{array}{l}\text { Boone J. 2015. Leading learning organizations through transformational change: } \\
\text { Making the case for blended learning. International Journal of Educational } \\
\text { Management 29(3):275-283. doi:10.1108/ijem-06-2013-0096 (Article) }\end{array}$ & Yes & No \\
\hline $\begin{array}{l}\text { Borland H. 2009. Conceptualising global strategic sustainability and corporate } \\
\text { transformational change. International Marketing Review 26(4-5):554-572. } \\
\text { doi:10.1108/02651330910972039 (Article) }\end{array}$ & Yes & No \\
\hline $\begin{array}{l}\text { Bos JJ, Brown RR and Farrelly MA. 2015. Building networks and coalitions to } \\
\text { promote transformational change: Insights from an Australian urban water planning } \\
\text { case study. Environmental Innovation and Societal Transitions 15:11-25. doi:10.1016/j. } \\
\text { eist.2014.10.002 (Article) }\end{array}$ & Yes & Yes \\
\hline $\begin{array}{l}\text { Brand MJ, Croonen EPM and Welsh DHB. 2016. Successfully managing chain-wide } \\
\text { transformational change. Organizational Dynamics 45(2):94-103. doi:10.1016/j. } \\
\text { orgdyn.2016.02.003 (Article) }\end{array}$ & Yes & No \\
\hline $\begin{array}{l}\text { Brandis S, Fisher R, McPhail R, Rice J, Eljiz K, Fitzgerald A, Gapp R and Marshall } \\
\text { A. } 2016 \text {. Hospital employees' perceptions of fairness and job satisfaction at a time } \\
\text { of transformational change. Australian Health Review 40(3):292-298. doi:10.1071/ } \\
\text { ah15031 (Article) }\end{array}$ & Yes & No \\
\hline $\begin{array}{l}\text { Brockhaus M, Korhonen-Kurki K, Sehring J, Di Gregorio M, Assembe-Mvondo } \\
\text { S, Babon A, Bekele M, Gebara MF, Khatri DB, Kambire H et al. 2017. REDD+, } \\
\text { transformational change and the promise of performance-based payments: A } \\
\text { qualitative comparative analysis. Climate Policy 17(6):708-730. (Article) }\end{array}$ & Yes & Yes \\
\hline $\begin{array}{l}\text { Brown VA and Lambert JA. 2013. Collective learning for transformational change: } A \\
\text { guide to collaborative action. New York: Routledge. (Book) }\end{array}$ & No & $\begin{array}{l}\text { Yes - } \\
\text { Replacement }\end{array}$ \\
\hline $\begin{array}{l}\text { Burke AE, Guralnick S and Hicks P. 2010. The Association of Pediatric Program } \\
\text { Directors' Strategic Plan: An opportunity for transformational change. Academic } \\
\text { Pediatrics 10(4):220-221. doi:10.1016/j.acap.2010.05.001 (Editorial Material) }\end{array}$ & Yes & No \\
\hline $\begin{array}{l}\text { Celep A, Brenner S and Mosher-Williams R. 2016. Internal culture, external impact: } \\
\text { How a change-making culture positions foundations to achieve transformational } \\
\text { change. Foundation Review 8(1):116-129. doi:10.9707/1944-5660.1288 (Article) }\end{array}$ & Yes & No \\
\hline $\begin{array}{l}\text { Charlesworth K, Jamieson M, Davey R and Butler CD. 2016. Transformational } \\
\text { change in healthcare: An examination of four case studies. Australian Health Review } \\
\text { 40(2):163-167. doi:10.1071/ah15041 (Article) }\end{array}$ & Yes & No \\
\hline $\begin{array}{l}\text { Chen H, Bell RH, Larson GM, Smith RS, Prinz RA and Grosfeld JL. 2004. Resident } \\
\text { perceptions of the impact of work-hour restrictions on health care delivery } \\
\text { and surgical education:Time for transformational change - discussion. Surgery } \\
\text { 136(4):868-871. (Editorial Material) }\end{array}$ & Yes & No \\
\hline
\end{tabular}




\begin{tabular}{l} 
Citation (Publication type) \\
\hline Chumbler NR, Haggstrom D and Saleem JJ. 2011. Implementation of \\
health information technology in Veterans health administration to support \\
transformational change telehealth and personal health records. Medical Care \\
49(12):S36-S42. doi:10.1097/MLR.0b013e3181d558f9 (Article)
\end{tabular}

Cohen AR. 2003. Transformational change at Babson College: Notes from the firing line. Academy of Management Learning and Education 2(2):155-166. doi:10.5465/ amle.2003.9901672 (Editorial Material)

Cummings JA. 2018. Transformational change in parenting practices after child interpersonal trauma: A grounded theory examination of parental response. Child Abuse and Neglect 76:117-128. doi:10.1016/j.chiabu.2017.10.005 (Article)
Analysis

Level $1 \quad$ Level 2

Yes No

\section{Derner JD, Smart AJ, Toombs TP, Larsen D, McCulley RL, Goodwin J, Sims S and Yes Yes}

Roche LM. 2018. Soil health as a transformational change agent for US grazing lands management. Rangeland Ecology and Management 71(4):403-408. doi:10.1016/j. rama.2018.03.007 (Article)

Di Gregorio M, Brockhaus M, Cronin T, Muharrom E, Mardiah S and Santoso L.
2015. Peadlock or transformational change? Exploring public discourse on REDD+
across seven countries. Global Environmental Politics 15(4):63-84. doi:10.1162/
GLEP_a_00322 (Article)

Di Diodato G. 2013. Just clean your hands: Measuring the effect of a patient safety Yes No initiative on driving transformational change in a health care system. American Journal of Infection Control 41(11):1109-1111. doi:10.1016/j.ajic.2013.01.039 (Article)

Di Stefano R. 2013. Tracking transformational change at an area agency on aging. Yes No Generations - Journal of the American Society on Aging 37(2):78-80. (Article)

Douglas LN and Webster V. 2015. Readiness of chief executives for transformational Yes No change across health, councils and third sector in Scotland to lead public service reform: A grounded theory approach. International Journal of Integrated Care 15:2. (Meeting Abstract)

Durie R and Wyatt K. 2013. Connecting communities and complexity: A case Yes No study in creating the conditions for transformational change. Critical Public Health 23(2):174-187. doi:10.1080/09581596.2013.781266 (Article)

Fischer HM and Pollock TG. 2004. Effects of social capital and power on surviving Yes No transformational change: The case of initial public offerings. Academy of Management Journal 47(4):463-481. doi:10.2307/20159597 (Article)

Fletcher JK. 2004. The paradox of postheroic leadership: An essay on gender, power, Yes No and transformational change. Leadership Quarterly 15(5):647-661. doi:10.1016/j. leaqua.2004.07.004 (Article)

Forcehimes A. 2005a. The relationship between transformational change and the Yes No fourth step of Alcoholics Anonymous. Alcoholism - Clinical and Experimental Research 29(5):72A-72A. (Meeting Abstract)

Forcehimes A. 2005b. Transformational change in recovery. Alcoholism - Clinical and Yes No Experimental Research 29(5):189A-189A. (Meeting Abstract)

Fraser A, Elliott SF and Cohen D. 2012. Transformational change: The Northwick Yes No Park experience. International Journal of Stroke 7:31-31. (Meeting Abstract) 


\begin{tabular}{|c|c|c|}
\hline \multirow[t]{2}{*}{ Citation (Publication type) } & \multicolumn{2}{|l|}{ Analysis } \\
\hline & Level 1 & Level 2 \\
\hline $\begin{array}{l}\text { Fridahl } \mathbf{M} \text { and Johansson L. 2017. An assessment of the potential for spurring } \\
\text { transformational change through Nationally Appropriate Mitigation Actions } \\
\text { (NAMAs). Environmental Innovation and Societal Transitions 25:35-46. doi:10.1016/j. } \\
\text { eist.2016.11.003 (Article) }\end{array}$ & Yes & Yes \\
\hline $\begin{array}{l}\text { Garfield RL. 2009. Mental health policy development in the states: The piecemeal } \\
\text { nature of transformational change. Psychiatric Services 60(10):1329-1335. (Article) }\end{array}$ & Yes & No \\
\hline $\begin{array}{l}\text { Gerrard JA. 2015. Investigator-led science: Predict the unpredictable and be ready } \\
\text { to capture transformational change. Journal of the Royal Society of New Zealand } \\
\text { 45(2):122-125. doi:10.1080/03036758.2015.1011170 (Article) }\end{array}$ & Yes & No \\
\hline $\begin{array}{l}\text { Gillard R. 2016. Questioning the diffusion of resilience discourses in pursuit of } \\
\text { transformational change. Global Environmental Politics 16(1):13-20. doi:10.1162/ } \\
\text { GLEP_a_00334 (Article) }\end{array}$ & Yes & Yes \\
\hline $\begin{array}{l}\text { Gilpin-Jackson Y. 2017. Participant experiences of transformational change in large- } \\
\text { scale organization development interventions (LODIs). Leadership and Organization } \\
\text { Development Journal 38(3):419-432. doi:10.1108/lodj-12-2015-0284 (Article) }\end{array}$ & Yes & No \\
\hline $\begin{array}{l}\text { Grant GJ and Grant AH. 2006. Patient-controlled epidural analgesia and } \\
\text { transformational change. International Journal of Obstetric Anesthesia 15(2):170-170. } \\
\text { doi:10.1016/j.ijoa.2005.10.017 (Letter) }\end{array}$ & Yes & No \\
\hline $\begin{array}{l}\text { Grant GJ, Grant AH and Lockwood CJ. 2005a. Simpson, Semmelweis and } \\
\text { transformational change - in reply. Obstetrics and Gynecology 106(5):1 1 108-1108. } \\
\text { doi:10.1097/01.AOG.0000186255.52346.e3 (Letter) }\end{array}$ & Yes & No \\
\hline $\begin{array}{l}\text { Grant GJ, Grant AH and Lockwood CJ. 2005b. Simpson, Semmelweis and } \\
\text { transformational change. Obstetrics and Gynecology 106(2):384-387. doi:10.1097/01. } \\
\text { aog.0000168452.10067.27 (Editorial Material) }\end{array}$ & Yes & No \\
\hline $\begin{array}{l}\text { Greenhalgh L and Nasser J. 2000. Ford Motor Company's CEO Jac Nasser on } \\
\text { transformational change, e-business, and environmental responsibility. Academy } \\
\text { of Management Executive 14(3):46-51. doi:10.5465/ame.2000.4468065 (Editorial } \\
\text { Material) }\end{array}$ & Yes & No \\
\hline $\begin{array}{l}\text { Gualandris J and Klassen RD. 2018. Emerging discourse incubator: Delivering } \\
\text { transformational change - aligning supply chains and stakeholders in non- } \\
\text { governmental organizations. Journal of Supply Chain Management 54(2):34-48. } \\
\text { (Article) }\end{array}$ & Yes & No \\
\hline $\begin{array}{l}\text { Gunderson L and Folke C. 2011. Resilience 2011: Leading transformational change. } \\
\text { Ecology and Society 16(2):3. (Editorial Material) }\end{array}$ & Yes & $\begin{array}{l}\text { No - } \\
\text { Replaced }\end{array}$ \\
\hline $\begin{array}{l}\text { Harmon RB, Fontaine D, Plews-Ogan M and Williams A. 2012. Achieving } \\
\text { transformational change: Using appreciative inquiry for strategic planning in a } \\
\text { school of nursing. Journal of Professional Nursing 28(2):119-124. doi:10.1016/j. } \\
\text { profnurs.2011.11.007 (Article) }\end{array}$ & Yes & No \\
\hline $\begin{array}{l}\text { Hawkins J. 2018. Transformational change in environmental and natural resource } \\
\text { management: Guidelines for policy excellence. Australian Journal of Agricultural and } \\
\text { Resource Economics 62(3):501-503. (Book Review) }\end{array}$ & Yes & $\begin{array}{l}\text { No- } \\
\text { Replaced }\end{array}$ \\
\hline $\begin{array}{l}\text { Holland B. 2017. Procedural justice in local climate adaptation: Political capabilities } \\
\text { and transformational change. Environmental Politics 26(3):391-412. doi:10.1080/0964 } \\
4016.2017 .1287625 \text { (Article) }\end{array}$ & Yes & Yes \\
\hline
\end{tabular}




\begin{tabular}{|c|c|c|}
\hline \multirow[t]{2}{*}{ Citation (Publication type) } & \multicolumn{2}{|l|}{ Analysis } \\
\hline & Level 1 & Level 2 \\
\hline $\begin{array}{l}\text { Horst SO and Jarventie-Thesleff R. } 2016 \text {. Finding an emergent way through } \\
\text { transformational change: A narrative approach to strategy. Journal of Media Business } \\
\text { Studies 13(1):3-21. doi:10.1080/16522354.2015.1123854 (Article) }\end{array}$ & Yes & No \\
\hline $\begin{array}{l}\text { Hunter DJ, Erskine J, Small A, McGovern T, Hicks C, Whitty P and Lugsden E. } \\
\text { 2015. Doing transformational change in the English NHS in the context of 'big bang' } \\
\text { redisorganization: Findings from the North East transformation system. Journal of } \\
\text { Health Organization and Management 29(1):10-24. doi:10.1108/jhom-01-2014-0019 } \\
\text { (Article) }\end{array}$ & Yes & No \\
\hline $\begin{array}{l}\text { Hurley C, Baum F and Eyk H. 2004. 'Designing better health care in the South': A } \\
\text { case study of unsuccessful transformational change in public sector health service } \\
\text { reform. Australian Journal of Public Administration 63(2):31-41. doi:10.1111/j.1467- } \\
8500.2004 .00376 . x \text { (Article) }\end{array}$ & Yes & No \\
\hline $\begin{array}{l}\text { Jacobs B, Cordell D, Chin J and Rowe H. 2017. Towards phosphorus sustainability } \\
\text { in North America: A model for transformational change. Environmental Science and } \\
\text { Policy 77:151-159. doi:10.1016/j.envsci.2017.08.009 (Article) }\end{array}$ & Yes & Yes \\
\hline $\begin{array}{l}\text { Jadvar H and Ballas LK. 2018. PSMA PET: Transformational change in prostate } \\
\text { cancer management? Journal of Nuclear Medicine 59(2):228-229. doi:10.2967/ } \\
\text { jnumed.117.203604 (Editorial Material) }\end{array}$ & Yes & No \\
\hline
\end{tabular}

\begin{tabular}{llc}
$\begin{array}{l}\text { Jordan G, Cowan T, Malla A and lyer S. 2018. A qualitative investigation of positive, } \\
\text { transformational change following a first episode of psychosis. International Journal } \\
\text { of Qualitative Methods 17(1):23-23. (Meeting Abstract) }\end{array}$ & Yes \\
\hline $\begin{array}{l}\text { Jorm CM. 2010. Patient safety: Time for a transformational change in medical } \\
\text { education. Medical Journal of Australia 193(8):487-488. (Letter) }\end{array}$ & Yes & No \\
\hline $\begin{array}{l}\text { Karunanayaka SP and Naidu S. 2018. Designing capacity building of educators in } \\
\text { open educational resources integration leads to transformational change. Distance } \\
\text { Education 39(1):87-109. doi:10.1080/01587919.2017.1413933 (Article) }\end{array}$ & Yes & No \\
\hline
\end{tabular}

Kezar A. 2013. Understanding sensemaking/sensegiving in transformational change Yes No processes from the bottom up. Higher Education 65(6):761-780. doi:10.1007/s10734012-9575-7 (Article) Kidd S, Kenny A and McKinstry C. 2014. Creating transformational change in
community mental health services. International Journal of Qualitative Methods 13:522-523. (Meeting Abstract)

King CS and Beeby M. 2008. Colleen Jollie, State Tribal Liaison: A story of Yes No transformational change. Public Administration Review 68(6):1142-1150. doi:10.1111/ j.1540-6210.2008.00961.x (Biography)

Kneebone R. 2009. Perspective: Simulation and transformational change: The paradox of expertise. Academic Medicine 84(7):954-957. doi:10.1097/ ACM.0b013e3181a843d6 (Article)

Kort KC, Pavone LA, Jensen E, Haque E, Newman N and Kittur D. 2004. Resident Yes No perceptions of the impact of work-hour restrictions on health care delivery and surgical education: Time for transformational change. Surgery 136(4):861-868. doi:10.1016/j.surg.2004.07.005 (Article)

Kramer R. 2016. Dialogic organization development: The theory and practice of Yes No transformational change. Academy of Management Learning and Education 15(3):639643. doi:10.5465/amle.2016.0207 (Book Review) 


\begin{tabular}{lll}
\hline Citation (Publication type) & \multicolumn{2}{l}{ Analysis } \\
\cline { 2 - 3 } & Level 1 Level 2 \\
\hline $\begin{array}{l}\text { Kuntz JRC and Gomes JFS. 2012. Transformational change in organisations: A self- } \\
\text { regulation approach. Journal of Organizational Change Management 25(1):143-162. } \\
\text { doi:10.1108/09534811211199637 (Article) }\end{array}$ & Yes & No \\
\hline $\begin{array}{l}\text { Langton N, Khan KM and Lusina SJ. 2010. FIFA's Football for Health: Applying } \\
\text { Kotter's eight-step program for transformational change to a mass participation } \\
\text { activity. British Journal of Sports Medicine 44(8):537-539. doi:10.1136/ } \\
\text { bjsm.2010.075143 (Editorial Material) }\end{array}$ & Yes & No \\
\hline
\end{tabular}

Lee DHL and Lee WO. 2018. Transformational change in instruction with professional Yes No learning communities? The influence of teacher cultural disposition in high power distance contexts. Journal of Educational Change 19(4):463-488. doi:10.1007/s10833018-9328-1 (Article)

\begin{tabular}{|c|c|c|}
\hline $\begin{array}{l}\text { Luce BR, Kramer JM, Goodman SN, Connor JT, Tunis S, Whicher D and Schwartz } \\
\text { JS. 2009. Rethinking randomized clinical trials for comparative effectiveness research: } \\
\text { The need for transformational change. Annals of Internal Medicine 151(3):206-W245. } \\
\text { doi:10.7326/0003-4819-151-3-200908040-00126 (Article) }\end{array}$ & Yes & No \\
\hline $\begin{array}{l}\text { Lukas CV, Holmes SK, Cohen AB, Restuccia J, Cramer IE, Shwartz M and Charns } \\
\text { MP. 2007. Transformational change in health care systems: An organizational } \\
\text { model. Health Care Management Review 32(4):309-320. doi:10.1097/01. } \\
\text { HMR.0000296785.29718.5d (Article) }\end{array}$ & Yes & No \\
\hline
\end{tabular}

Mapfumo P, Onyango M, Honkponou SK, El Mzouri E, Githeko A, Rabeharisoa L, Yes Yes Obando J, Omolo N, Majule A, Denton F, et al. 2017. Pathways to transformational change in the face of climate impacts: An analytical framework. Climate and Development 9(5):439-451. doi:10.1080/17565529.2015.1040365 (Article)

McAlpine CA, Seabrook LM, Ryan JG, Feeney BJ, Ripple WJ, Ehrlich AH and Ehrlich PR. 2015. Transformational change: Creating a safe operating space for humanity. Ecology and Society 20(1):6. doi:10.5751/es-07181-200156 (Article)

McGrath KM, Bennett DM, Ben-Tovim DI, Boyages SC, Lyons NJ and O'Connell TJ. Yes No 2008. Implementing and sustaining transformational change in health care: Lessons learnt about clinical process redesign. Medical Journal of Australia 188(7):422-422. (Correction)

McGrath KM, Bennett DM, Ben-Tovim DI, Boyages SC, Lyons NJ and O'Connell TJ. Yes No 2008. Implementing and sustaining transformational change in health care: Lessons learnt about clinical process redesign. Medical Journal of Australia 188(6):S32-S35. (Article)

McNaney N and Bradbury E. 2016a. Developing systems leadership for Yes No transformational change. International Journal of Integrated Care 16:1. doi:10.5334/ ijic.2892 (Meeting Abstract)

McNaney $\mathbf{N}$ and Bradbury E. 2016b. Practical tools for transformational change. International Journal of Integrated Care 16:2. doi:10.5334/ijic.2893 (Meeting Abstract)

Moore TE. 2003. Transformational change at Babson: Before the first shot was fired. Yes No Academy of Management Learning and Education 2(2):170-172. (Editorial Material)

Nam K, Oh SW, Kim SK, Goo J and Khan MS. 2016. Dynamics of enterprise Yes No architecture in the Korean public sector: Transformational change vs. transactional change. Sustainability 8(11):18. doi:10.3390/su8111074 (Article)

Nicholson KP. 2015. The McDonaldization of academic libraries and the values of transformational change. College and Research Libraries 76(3):328-338. doi:10.5860/ Yes No crl.76.3.328 (Article) 


\begin{tabular}{|c|c|c|}
\hline \multirow[t]{2}{*}{ Citation (Publication type) } & \multicolumn{2}{|c|}{ Analysis } \\
\hline & Level 1 & Level 2 \\
\hline $\begin{array}{l}\text { Pagoropoulos A, Maier A and McAloone TC. 2017. Assessing transformational } \\
\text { change from institutionalising digital capabilities on implementation and } \\
\text { development of Product-Service Systems: Learnings from the maritime industry. } \\
\text { Journal of Cleaner Production 166:369-380. doi:10.1016/j.jclepro.2017.08.019 (Article) }\end{array}$ & Yes & No \\
\hline $\begin{array}{l}\text { Ramberg U. 2017. Transformational change and the vacuum of performance } \\
\text { measurement: How a story of success became a failure. Financial Accountability and } \\
\text { Management 33(3):249-263. doi:10.1111/faam.12123 (Article) }\end{array}$ & Yes & No \\
\hline $\begin{array}{l}\text { Riley WJ, Parsons HM, Duffy GL, Moran JW and Henry B. 2010. Realizing } \\
\text { transformational change through quality improvement in public health. Journal of } \\
\text { Public Health Management and Practice 16(1):72-78. (Article) }\end{array}$ & Yes & No \\
\hline $\begin{array}{l}\text { Romanow RJ and Marchildon GP. 2004. History, politics and transformational } \\
\text { change in Canadian health care: A rejoinder. Canadian Psychology - Psychologie } \\
\text { Canadienne 45(3):239-243. doi:10.1037/h0086994 (Article) }\end{array}$ & Yes & No \\
\hline $\begin{array}{l}\text { Ross H. 2013. Collective learning for transformational change: A guide to } \\
\text { collaborative action. Australasian Journal of Environmental Management 20(3):257- } \\
\text { 259. doi:10.1080/14486563.2013.826121 (Book Review) }\end{array}$ & Yes & $\begin{array}{l}\text { No - } \\
\text { Replaced }\end{array}$ \\
\hline $\begin{array}{l}\text { Runciman WB. 2010. Patient safety: Time for a transformational change in medical } \\
\text { education. Medical Journal of Australia 193(1):3-4. (Editorial Material) }\end{array}$ & Yes & No \\
\hline $\begin{array}{l}\text { Rutty JE, Morgan B and Rutty GN. 2015. Managing transformational change: } \\
\text { Implementing cross-sectional imaging into death investigation services in the } \\
\text { United Kingdom. Journal of Forensic Radiology and Imaging 3(1):57-60. doi:10.1016/j. } \\
\text { jofri.2014.11.003 (Editorial Material) }\end{array}$ & Yes & No \\
\hline $\begin{array}{l}\text { Sampson J. 2010. Developing a strategy for the management of change which } \\
\text { covers continuous improvement, transformational change and discontinuous } \\
\text { innovation through consideration of double-loop learning. Vox Sanguinis 99:91-92. } \\
\text { (Meeting Abstract) }\end{array}$ & Yes & No \\
\hline $\begin{array}{l}\text { Sayles C. 2002. Transformational change - Based on the model of Virginia Satir. } \\
\text { Contemporary Family Therapy 24(1):93-109. doi:10.1023/a:1014325722738 (Article) }\end{array}$ & Yes & No \\
\hline $\begin{array}{l}\text { Schoon M, Fabricius C, Anderies JM and Nelson M. 2011. Synthesis: Vulnerability, } \\
\text { traps and transformations - long-term perspectives from archaeology. Ecology and } \\
\text { Society 16(2):24. (Article) }\end{array}$ & No & $\begin{array}{l}\text { Yes - } \\
\text { Replacement }\end{array}$ \\
\hline $\begin{array}{l}\text { Scott SM. 2017. Collective learning for transformational change: A guide } \\
\text { to collaborative action. Journal of Transformative Education 15(1):95-97. } \\
\text { doi:10.1177/1541344616629792 (Book Review) }\end{array}$ & Yes & $\begin{array}{l}\text { No- } \\
\text { Replaced }\end{array}$ \\
\hline $\begin{array}{l}\text { Seijts GH and Gandz J. 2018. Transformational change and leader character. Business } \\
\text { Horizons 61(2):239-249. doi:10.1016/j.bushor.2017.11.005 (Article) }\end{array}$ & Yes & No \\
\hline $\begin{array}{l}\text { Sengupta M. 2018. Transformational change or tenuous wish list? A critique of SDG } 1 \\
\text { ('End poverty in all its forms everywhere'). Social Alternatives 37(1):12-17. (Article) }\end{array}$ & Yes & No \\
\hline $\begin{array}{l}\text { Shirey MR. 2011. Establishing a sense of urgency for leading transformational } \\
\text { change. Journal of Nursing Administration 41(4):145-148. doi:10.1097/ } \\
\text { NNA.0b013e3182118550 (Article) }\end{array}$ & Yes & No \\
\hline $\begin{array}{l}\text { Skogland MAC. 2017. A spatial approach to transformational change Strategic } \\
\text { alignment of the spatial and cultural environment. Journal of Corporate Real Estate } \\
\text { 19(4):285-299. doi:10.1108/jcre-09-2016-0030 (Article) }\end{array}$ & Yes & No \\
\hline
\end{tabular}




\begin{tabular}{|c|c|c|}
\hline \multirow[t]{2}{*}{ Citation (Publication type) } & \multicolumn{2}{|c|}{ Analysis } \\
\hline & Level 1 & Level 2 \\
\hline $\begin{array}{l}\text { Springer PJ, Clark CM, Strohfus P and Belcheir M. 2012. Using transformational } \\
\text { change to improve organizational culture and climate in a school of nursing. Journal } \\
\text { of Nursing Education 51(2):80-87. doi:10.3928/01484834-20111230-02 (Article) }\end{array}$ & Yes & No \\
\hline $\begin{array}{l}\text { Stotland NE and Stotland NL. 2005. Simpson, Semmelweis and transformational } \\
\text { change. Obstetrics and Gynecology 106(5):1107-1108. doi:10.1097/01. } \\
\text { aog.0000186050.56229.93 (Letter) }\end{array}$ & Yes & No \\
\hline $\begin{array}{l}\text { Sutherland JR. 2010. Patient safety: Time for a transformational change in medical } \\
\text { education. Medical Journal of Australia 193(8):487-487. (Letter) }\end{array}$ & Yes & No \\
\hline $\begin{array}{l}\text { Swanson RC, Cattaneo A, Bradley E, Chunharas S, Atun R, Abbas KM, Katsaliaki } \\
\text { K, Mustafee N, Meier B and Best A. 2012. Rethinking health systems strengthening: } \\
\text { Key systems thinking tools and strategies for transformational change. Health Policy } \\
\text { and Planning 27:54-61. doi:10.1093/heapol/czs090 (Editorial Material) }\end{array}$ & Yes & No \\
\hline $\begin{array}{l}\text { Tassabehji R, Hackney R and Popovic A. 2016. Emergent digital era governance: } \\
\text { Enacting the role of the 'institutional entrepreneur' in transformational change. } \\
\text { Government Information Quarterly 33(2):223-236. doi:10.1016/j.giq.2016.04.003 } \\
\text { (Article) }\end{array}$ & Yes & No \\
\hline $\begin{array}{l}\text { Termeer C, Dewulf A and Biesbroek GR. 2017. Transformational change: } \\
\text { Governance interventions for climate change adaptation from a continuous change } \\
\text { perspective. Journal of Environmental Planning and Management 60(4):558-576. doi:1 } \\
0.1080 / 09640568.2016 .1168288 \text { (Article) }\end{array}$ & Yes & Yes \\
\hline $\begin{array}{l}\text { Totin E, Butler JR, Sidibe A, Partey S, Thornton PK and Tabo R. 2018. Can scenario } \\
\text { planning catalyze transformational change? Evaluating a climate change policy case } \\
\text { study in Mali. Futures } 96: 44-56 \text {. doi:10.1016/j.futures.2017.11.005 (Article) }\end{array}$ & Yes & Yes \\
\hline $\begin{array}{l}\text { Walsh CL, Glendinning S, Castan-Broto V, Dewberry E and Powell M. } 2015 . \\
\text { Are wildcard events on infrastructure systems opportunities for transformational } \\
\text { change? Futures 67:1-10. doi:10.1016/j.futures.2015.01.005 (Article) }\end{array}$ & Yes & No \\
\hline $\begin{array}{l}\text { Weaver L. 2016. Possible: Transformational change in collective impact. Community } \\
\text { Development 47(2):274-283. doi:10.1080/15575330.2016.1138977 (Article) }\end{array}$ & Yes & No \\
\hline $\begin{array}{l}\text { Weerakkody V, Janssen M and Dwivedi YK. 2011. Transformational change } \\
\text { and business process reengineering (BPR): Lessons from the British and Dutch } \\
\text { public sector. Government Information Quarterly 28(3):320-328. doi:10.1016/j. } \\
\text { giq.2010.07.010 (Article) }\end{array}$ & Yes & No \\
\hline $\begin{array}{l}\text { White WL. 2004. Transformational change: A historical review. Journal of Clinical } \\
\text { Psychology 60(5):461-470. doi:10.1002/jclp.20001 (Article) }\end{array}$ & Yes & No \\
\hline $\begin{array}{l}\text { Wiek A, Ness B, Schweizer-Ries P, Brand FS and Farioli F. 2012. From complex } \\
\text { systems analysis to transformational change: A comparative appraisal of } \\
\text { sustainability science projects. Sustainability Science 7:5-24. doi:10.1007/s11625-011- } \\
0148-y \text { (Article) }\end{array}$ & Yes & Yes \\
\hline $\begin{array}{l}\text { Williamson JAH. 2010. Patient safety: Time for a transformational change in medical } \\
\text { education. Medical Journal of Australia 193(8):487-487. (Letter) }\end{array}$ & Yes & No \\
\hline $\begin{array}{l}\text { Willis CD, Best A, Riley B, Herbert CP, Millar J and Howland D. 2014. Systems } \\
\text { thinking for transformational change in health. Evidence and Policy 10(1):113-126. } \\
\text { doi:10.1332/174426413x662815 (Article) }\end{array}$ & Yes & No \\
\hline $\begin{array}{l}\text { Winkler H and Dubash NK. 2016. Who determines transformational change in } \\
\text { development and climate finance? Climate Policy 16(6):783-791. doi:10.1080/146930 } \\
62.2015 .1033674 \text { (Article) }\end{array}$ & Yes & Yes \\
\hline
\end{tabular}




\begin{tabular}{llc}
\hline Citation (Publication type) & Analysis \\
\cline { 2 - 3 } & Level $\mathbf{1}$ Level 2 \\
\hline $\begin{array}{l}\text { Wolf G, Bradle J and Nelson G. 2005. Bridging the strategic leadership gap: A model } \\
\text { program for transformational change. Journal of Nursing Administration 35(2):54-60. } \\
\text { (Article) }\end{array}$ & Yes & No \\
\hline $\begin{array}{l}\text { Young M and Esau C, eds. 2016. Transformational change in environmental and } \\
\text { natural resource management: Guidelines for Policy Excellence. Routledge. (Book) }\end{array}$ & No & Yes - \\
\hline $\begin{array}{l}\text { Zolner JP. 2003. Transformational change at Babson College: A view from the } \\
\text { outside. Academy of Management Learning and Education 2(2):177-180. (Editorial } \\
\text { Material) }\end{array}$ & Yes & No \\
\hline
\end{tabular}

\section{Annex 3. Learning from the land-use sector (agriculture, forestry and other land uses): Transformational change definitions and concepts that relate to climate change and other disciplines}

Note: The emphasis in this table was added by the authors of this report

\begin{tabular}{ll}
\hline Context & Definition/description of transformational change \\
\hline $\begin{array}{l}\text { Climate change } \\
\text { adaptation and } \\
\text { mitigation }\end{array}$ & $\begin{array}{l}\text { "What is crucial, however, is that the Board's ambition to get the Fund off the ground and up } \\
\text { to scale swiftly does not compromise on its ambition to promote cutting-edge innovation } \\
\text { and real transformation towards the low-emission and climate-resilient future that the } \\
\text { global community committed itself to in the Paris Agreement." (GCF, cited in Puri 2018, 3) }\end{array}$ \\
& "...the GCF will promote the paradigm shift towards low-emission and climate-resilient \\
& $\begin{array}{l}\text { development pathways by providing support to developing countries to limit or reduce } \\
\text { their greenhouse gas emissions and to adapt to the impacts of climate change, taking into } \\
\text { account the needs of those developing countries particularly vulnerable to the adverse } \\
\text { effects of climate change." (GCF, cited in Puri 2018, 3) }\end{array}$
\end{tabular}

Climate change "a fundamental qualitative change ... that often involves a change in paradigm and may adaptation include shifts in perception and meaning, changes in underlying norms and values, reconfiguration of social networks and patterns of interaction, changes in power structures, and the introduction of new institutional arrangements and regulatory frameworks." (IPCC 2012, 436)

"... adaptation is understood as an ongoing process of transformation, in which vulnerable populations come to have voice and power in the struggle among competing interests." (Holland 2017, 8)

"Transformation entails a significant shift in characteristic features and functions, resulting in a fundamentally new system or process whether economic, social or ecological." (Mapfumo et al. 2017, 440)

"... the size/extent and intensity of a change often characterize transformational shifts. Change that is discontinuous, qualitatively distinctive and has a broad spatial coverage is often also viewed as transformational .... Irreversibility and long duration are other characteristics sometimes attributed to transformational changes and responses." (Mapfumo et al. 2017, 440)

"However, given the relative newness of interventions to support climate change adaptation in recent years, and the short duration of many development interventions related to climate risks, it is necessary to think of transformation in ways that do not only hinge on an assessment of size and scale." (Mapfumo et al. 2017, 440) 


\begin{tabular}{ll}
\hline Context & Definition/description of transformational change \\
\hline $\begin{array}{l}\text { Climate change } \\
\text { mitigation }\end{array}$ & $\begin{array}{l}\text { "... deep, long-term, structural changes that address the root causes of carbon lock-in } \\
\text { through a series of incremental steps ... a structural change that alters the interplay of } \\
\text { institutional, cultural, technological, economic and ecological dimensions" (Boodoo et al. } \\
2018,683) \\
\end{array}$ \\
& "... occur[s] when regimes are destabilized under the influence of pressures from niches \\
& and landscape factors." (Boodoo and Olsen 2018, 796)
\end{tabular}

"... [a] shift in discourse, attitudes, power relations, and deliberate policy and protest action that leads policy formulation and implementation away from business as usual policy approaches that directly or indirectly support deforestation and forest degradation." (Brockhaus and Angelsen 2012, 16; adopted by Babon et al. (2014), Di Gregorio et al. (2015) and Brockhaus et al. (2017))

Natural resource Transitions involve gradual, continuous processes of change along a range of possible management development paths at varying scales and speeds, and can be described as a set of connected changes. These pathways may reinforce each other but take place in diverse areas, like technology, the economy, institutions, human behavior and beliefs, culture and ecology. Transformed systems are achieved through knowledge sharing of success and selforganization of the social system." (Jacobs et al. 2017)

International development

"Transformational change is the process whereby positive development results are achieved and sustained over time by institutionalizing policies, programs and projects within national strategies. ... this embodies the concept of institutionally sustained results - consistency of achievement over time. This is in order to exclude short-term, transitory impact." (UNDP 2011, 7)

"GEF 2020 emphasizes the need for us to support transformational change and achieve impacts on a broader scale."

"The 2020 vision for the GEF is to be a champion of the global environment building on its role as financial mechanism of several multilateral environmental conventions (MEAs), supporting transformational change, and achieving global environmental benefits on a larger scale." (Global Environment Facility (GEF), cited in Puri 2018, 3)

"Transforming the trajectory to maintain the historical trend requires a concerted effort by the international development community to bend the 'natural arc' of history." (World Bank, cited in Puri 2018, 3)

"We need to move decisively beyond the remnants of a one-size-fits-all approach and recognize the full extent of the diversity and complexity of our client base, then tailor solutions to each client."(World Bank, cited in Puri 2018, 3)

"FAO is working closely with governments and their stakeholders to select national targets, implement and monitor progress in line with the overall vision and aspirations of the 2030 Agenda." (FAO, cited in Puri 2018, 3)

"A structural change that alters the interplay of institutional, cultural, technological, economic and ecological dimensions of a given system. It will unlock new development paths, including social practices and worldviews." (Mersmann et al. 2014 10, commissioned by BMZ, the German Federal Ministry for Economic Cooperation and Development) Characteristics of transformational change processes: Intense (fundamental restructuring of the system, shift of predominant paradigms, complex non-linear processes, change in multiple dimensions); socially dynamic (driven by pioneers with a vision of change, emergence of new networks and coalitions, and conflicts as power structures change); and temporally dynamic (long time span, gradual changes through incremental steps, with tipping points where the stability of the former systems break). (Adapted from Table 2.1 in Mersmann et al. 2014) 


\begin{tabular}{ll}
\hline Context & Definition/description of transformational change \\
\hline $\begin{array}{l}\text { Collective } \\
\text { learning }\end{array}$ & "changes in a local community or involving an entire nation ... [or] the entire globe ... \\
& $\begin{array}{l}\text { take place on each of these levels at the same time ... go beyond incremental change } \\
\text { to changes that alter the context in which it is taking place. It is not business as usual, } \\
\text { and tomorrow will not be the same as yesterday ... a change in the way we think, and } \\
\text { especially to our understanding of the world we live in." (Brown n.d.) }\end{array}$ \\
\hline
\end{tabular}

\section{Annex 4. Summary of the drivers of transformational change found in academic literature}

Note: Twelve of 22 land-use and climate change articles are included in this analysis

\begin{tabular}{|c|c|c|c|c|c|c|}
\hline \multirow[t]{2}{*}{ Context } & \multirow{2}{*}{$\begin{array}{l}\text { Scientific article and } \\
\text { desired transformational } \\
\text { change }\end{array}$} & \multirow[t]{2}{*}{$\begin{array}{l}\text { Possible drivers (Exogenous, Endogenous, } \\
\text { Barriers)a }\end{array}$} & \multicolumn{4}{|c|}{$\begin{array}{l}\text { Driver } \\
\text { groups }^{b}\end{array}$} \\
\hline & & & $\mathbf{R}$ & $\mathrm{L}$ & $P$ & $\mathbf{N}$ \\
\hline \multirow{7}{*}{$\begin{array}{l}\text { Climate } \\
\text { change } \\
\text { mitigation }\end{array}$} & \multirow{2}{*}{$\begin{array}{l}\text { Transformational change in } \\
\text { the REDD+ policy arena in } \\
\text { Papua New Guinea (Babon } \\
\text { et al. 2014) }\end{array}$} & $\begin{array}{l}\text { Exogenous: Global debate supporting REDD+ }(\mathrm{L} \text {, } \\
\mathrm{P}) \text {; emerging global carbon markets }(\mathrm{R}, \mathrm{L})\end{array}$ & $x$ & $x$ & $x$ & \\
\hline & & $\begin{array}{l}\text { Endogenous: National REDD+ actions (R); } \\
\text { improved resources of advocacy coalitions (R); } \\
\text { dominance of advocacy coalition actions over } \\
\text { status quo coalitions (L) }\end{array}$ & $x$ & $x$ & & \\
\hline & $\begin{array}{l}\text { Transformational change } \\
\text { in the REDD+ policy arenas } \\
\text { ( } 13 \text { countries) (Brockhaus } \\
\text { et al. 2017) }\end{array}$ & $\begin{array}{l}\text { Endogenous: Results-based payments, when } \\
\text { there is high national ownership }(R, L) \text {; non- } \\
\text { performance based payments, when there is no } \\
\text { national ownership }(R, L)\end{array}$ & $x$ & $x$ & & \\
\hline & \multirow[t]{2}{*}{$\begin{array}{l}\text { REDD+ policy reforms in } 7 \\
\text { countries (Di Gregorio et al. } \\
\text { 2015) }\end{array}$} & $\begin{array}{l}\text { Endogenous: Reformist policy actors and the } \\
\text { media engaging dominant policy actors on how } \\
\text { to reduce pressure on forest }(L, P)\end{array}$ & & $x$ & $x$ & \\
\hline & & $\begin{array}{l}\text { Barriers: Predominance of win-win storylines }(L) \text {; } \\
\text { state actors lack debates on potential negative } \\
\text { outcomes of REDD+ }(P) \text {; little attention to the } \\
\text { drivers of deforestation }(L, P)\end{array}$ & & $x$ & $x$ & \\
\hline & \multirow[t]{2}{*}{$\begin{array}{l}\text { Improve potential of } \\
\text { transformational change of } \\
\text { climate finance in Tunisia } \\
\text { (Boodoo et al. 2018) }\end{array}$} & $\begin{array}{l}\text { Exogenous: Climate finance debate at the global } \\
\text { level (R, L); climate finance from the Green } \\
\text { Climate Fund (GCF) and Nationally Appropriate } \\
\text { Mitigation Actions (NAMA) Facility (R) }\end{array}$ & $x$ & $x$ & & \\
\hline & & $\begin{array}{l}\text { Barriers: Disparities and fragmentation of } \\
\text { interests (L); difficulty reconciling accountability } \\
\text { with innovative open-ended approach ( } \mathrm{P}, \\
\mathrm{N}) \text {; difficult to apply transition management } \\
\text { principles in the developing-country context }(\mathrm{N})\end{array}$ & & $x$ & $x$ & $x$ \\
\hline
\end{tabular}




\begin{tabular}{|c|c|c|c|c|c|c|}
\hline \multirow[t]{2}{*}{ Context } & \multirow{2}{*}{$\begin{array}{l}\text { Scientific article and } \\
\text { desired transformational } \\
\text { change }\end{array}$} & \multirow[t]{2}{*}{$\begin{array}{l}\text { Possible drivers (Exogenous, Endogenous, } \\
\text { Barriers) }\end{array}$} & \multicolumn{4}{|c|}{$\begin{array}{l}\text { Driver } \\
\text { groups }^{\mathrm{b}}\end{array}$} \\
\hline & & & $\mathbf{R}$ & $\mathbf{L}$ & $P$ & $\mathrm{~N}$ \\
\hline & \multirow{3}{*}{$\begin{array}{l}\text { Reduce carbon emissions } \\
\text { from the cement industry } \\
\text { in Tunisia (Boodoo and } \\
\text { Olsen 2018) }\end{array}$} & $\begin{array}{l}\text { Exogenous: UNFCCC ratification, entailing (l) } \\
\text { NDCs and the NAMA registry }(\mathrm{R}, \mathrm{L}) \text {; donor } \\
\text { support for Cement NAMA in Tunisia }(\mathrm{R}, \mathrm{L})\end{array}$ & $x$ & $x$ & & \\
\hline & & $\begin{array}{l}\text { Endogenous: Closer interaction between regimes } \\
\text { (energy production and waste) }(\mathrm{P} ; \mathrm{N})\end{array}$ & & & $x$ & \\
\hline & & $\begin{array}{l}\text { Barriers: Increased prices of cleaner energy } \\
\text { sources }(R) \text {; locked into landfilling and the } \\
\text { national electric utility company }(R) \text {; industry } \\
\text { incumbents choose only win-win outcomes }(L \text {, } \\
N) \text {; industry incumbents are not reflexive }(N) \text {; } \\
\text { donors/financers were not engaged early in } \\
\text { coalition-building }(P, N) \text {; lack of social learning } \\
\text { built into the project design }(P, N) \text {; lack of } \\
\text { learning from implementation within and across } \\
\text { niches }(P, N)\end{array}$ & $x$ & $x$ & $x$ & $x$ \\
\hline \multirow[t]{4}{*}{$\begin{array}{l}\text { Climate } \\
\text { change } \\
\text { adaptation }\end{array}$} & $\begin{array}{l}\text { educe social vulnerability, } \\
\text { enhance systems resilience } \\
\text { and enable targeting of } \\
\text { actions against specific } \\
\text { climate risks. (Mapfumo et } \\
\text { al. } 2017\end{array}$ & $\begin{array}{l}\text { Endogenous: Learning from actions (N); } \\
\text { development of alliances and networks for } \\
\text { learning (P); presence of multiple reward } \\
\text { systems (R, L, P); willingness to empower } \\
\text { individuals/communities as change agents (e.g. } \\
\text { by providing access to information, facilitating } \\
\text { dialogue and collaboration) (N); actions are self- } \\
\text { sufficient (e.g. financing, human resources) (R) }\end{array}$ & $x$ & $x$ & $x$ & $x$ \\
\hline & \multirow{3}{*}{$\begin{array}{l}\text { Correct inequities, } \\
\text { focusing on changing } \\
\text { human agency rather than } \\
\text { vulnerability (Holland } \\
\text { 2017) }\end{array}$} & $\begin{array}{l}\text { Exogenous: Beliefs among powerful actors in } \\
\text { whether climate change is real }(\mathrm{N})\end{array}$ & & & & $x$ \\
\hline & & $\begin{array}{l}\text { Endogenous: Give vulnerable populations } \\
\text { control to shape adaptation actions }(N) \text {; ensure } \\
\text { people's preferences are well-informed }(R, N) \text {; } \\
\text { ensure vulnerable populations are free from } \\
\text { overt forms of domination or oppression }(P, N) \text {; } \\
\text { adopt policies that communities want regardless } \\
\text { of climate impacts occurring }(L, N)\end{array}$ & $x$ & $x$ & $x$ & $x$ \\
\hline & & $\begin{array}{l}\text { Barriers: Making decisions based on climate } \\
\text { models that may weaken claims of those without } \\
\text { scientific proof of probable harm }(L, N) \text {; reducing } \\
\text { discussions about climate change adaptation } \\
\text { to a series of engineering calculations }(L, N) \text {; } \\
\text { favoring 'scientific' knowledge over other forms } \\
\text { of knowledge }(L, N)\end{array}$ & & $x$ & & $x$ \\
\hline
\end{tabular}




\begin{tabular}{|c|c|c|c|c|c|c|}
\hline \multirow[t]{2}{*}{ Context } & \multirow{2}{*}{$\begin{array}{l}\text { Scientific article and } \\
\text { desired transformational } \\
\text { change }\end{array}$} & \multirow[t]{2}{*}{$\begin{array}{l}\text { Possible drivers (Exogenous, Endogenous, } \\
\text { Barriers) }^{\mathrm{a}}\end{array}$} & \multicolumn{4}{|c|}{$\begin{array}{l}\text { Driver } \\
\text { groups }^{b}\end{array}$} \\
\hline & & & $\mathbf{R}$ & $\mathrm{L}$ & $P$ & $\mathbf{N}$ \\
\hline \multirow[t]{2}{*}{$\begin{array}{l}\text { Sustainable } \\
\text { resource } \\
\text { management }\end{array}$} & \multirow[t]{2}{*}{$\begin{array}{l}\text { Improve water health } \\
\text { and water management } \\
\text { in the Cook River water } \\
\text { catchment, Sydney (Bos et } \\
\text { al. 2015) }\end{array}$} & $\begin{array}{l}\text { Exogenous: Grant program for partnership } \\
\text { between local government, businesses, NGOs, } \\
\text { residents (R, P); existing groups and individuals } \\
\text { with objectives similar to the change in question } \\
\text { (L); access to a network of science/knowledge } \\
\text { brokers (R) }\end{array}$ & $x$ & $x$ & $x$ & \\
\hline & & $\begin{array}{l}\text { Endogenous: Governance experimentation } \\
\text { based on past policy failures }(\mathrm{P}, \mathrm{N}) \text {; influential } \\
\text { and visionary frontrunners }(\mathrm{R}, \mathrm{L}) \text {; main transition } \\
\text { arena and sub-arenas share information and } \\
\text { make decisions }(\mathrm{P}) \text {; early investment in building } \\
\text { transition arena that is inclusive and diverse }(\mathrm{P}, \\
\mathrm{N}) \text {; real-time monitoring results used to form } \\
\text { new strategies for the whole catchment }(\mathrm{P}, \\
\mathrm{N}) \text {; form a political coalition in support of the } \\
\text { transformational change }(\mathrm{L}, \mathrm{P})\end{array}$ & & $x$ & $x$ & $x$ \\
\hline \multirow[t]{5}{*}{$\begin{array}{l}\text { Sustainable } \\
\text { resource } \\
\text { management }\end{array}$} & \multirow{3}{*}{$\begin{array}{l}\text { Improve commitment } \\
\text { across a large number of } \\
\text { people (e.g. city, region) } \\
\text { to act and live more } \\
\text { sustainably (Brown and } \\
\text { Lambert } 2013\end{array}$} & $\begin{array}{l}\text { Exogenous: Well-educated professionals }(\mathrm{R}) ; \mathrm{a} \\
\text { concerned citizenry; a web of local organizations } \\
\text { with overlapping interests }(\mathrm{R}, \mathrm{L})\end{array}$ & $x$ & $x$ & & \\
\hline & & $\begin{array}{l}\text { Endogenous: Working from values rather than } \\
\text { facts }(\mathrm{N}) \text {; working in small groups }(\mathrm{P}) \text {; stirring } \\
\text { deep wells of untapped imagination }(\mathrm{P}) \text {; series } \\
\text { of workshops engaging the four-stages of social } \\
\text { learning (Figure } 4)(\mathrm{P})\end{array}$ & & & $x$ & $x$ \\
\hline & & $\begin{array}{l}\text { Barrier: Regulation and broader business } \\
\text { interests }(R, L)\end{array}$ & $x$ & $x$ & & \\
\hline & \multirow[t]{2}{*}{$\begin{array}{l}\text { Encourage stewardship } \\
\text { and sustainable grazing } \\
\text { land management (Derner } \\
\text { et al. 2018) }\end{array}$} & $\begin{array}{l}\text { Endogenous: Linking natural resources } \\
\text { stewardship and sustainable grazing } \\
\text { management }(P, N) \text {; reaching broader audiences } \\
(P, N) \text {; communications among producers, } \\
\text { customers and the general public }(P, N) \text {; } \\
\text { establishing a network of living laboratories; } \\
\text { management-science partnerships }(P, N)\end{array}$ & & & $x$ & $x$ \\
\hline & & $\begin{array}{l}\text { Barrier: Actors prescribing practices assuming } \\
\text { benefits or outcomes }(\mathrm{N})\end{array}$ & & & & $x$ \\
\hline
\end{tabular}




\begin{tabular}{|c|c|c|c|c|c|c|}
\hline \multirow[t]{2}{*}{ Context } & \multirow{2}{*}{$\begin{array}{l}\text { Scientific article and } \\
\text { desired transformational } \\
\text { change }\end{array}$} & \multirow[t]{2}{*}{$\begin{array}{l}\text { Possible drivers (Exogenous, Endogenous, } \\
\text { Barriers) }\end{array}$} & \multicolumn{4}{|c|}{$\begin{array}{l}\text { Driver } \\
\text { groups }\end{array}$} \\
\hline & & & $\mathbf{R}$ & $\mathrm{L}$ & $P$ & $\mathrm{~N}$ \\
\hline & \multirow[t]{2}{*}{$\begin{array}{l}\text { Become low-carbon } \\
\text { societies (Fridahl and } \\
\text { Johansson } 2017\end{array}$} & $\begin{array}{l}\text { Exogenous: Structures in the country serving as a } \\
\text { support system, like policy or law }(R) \text {; regulatory } \\
\text { support systems for niches, to increase the } \\
\text { likelihood innovations are scaled up }(R, N)\end{array}$ & $x$ & & & $x$ \\
\hline & & $\begin{array}{l}\text { Endogenous: Action affecting multiple areas of } \\
\text { the system }(P, N) \text {; supporting the development } \\
\text { or scaling up an existing niche, or developing } \\
\text { a new one }(R, N) \text {; acknowledging the need for } \\
\text { a learning process }(N) \text {; bringing together a } \\
\text { shared positive vision among diverse actors ( } P, \\
N) \text { learning by trial and error }(N) \text {; encouraging } \\
\text { strong social networks through participatory } \\
\text { processes }(P, N) \text {; long-term financial support } \\
\text { from donors }(R, N) \text {; allowing niches to learn from } \\
\text { errors and build networks }(N) \text {; inducing change } \\
\text { at multiple levels of socio-technical systems ( } P, \\
\text { N) }\end{array}$ & $x$ & & $x$ & $x$ \\
\hline & \multirow[t]{2}{*}{$\begin{array}{l}\text { Improve the sustainability } \\
\text { of phosphorus supply to } \\
\text { improve socio-ecological } \\
\text { resilience (Jacobs et al. } \\
\text { 2017) }\end{array}$} & $\begin{array}{l}\text { Exogenous: Environmental catastrophe } \\
\text { caused by too much phosphorous run-off } \\
\text { (L); the closure of the only phosphate mine } \\
\text { in Canada, which increased North American } \\
\text { dependence on overseas imports and the value } \\
\text { of phosphorous (L); government interest in food } \\
\text { security (L) }\end{array}$ & & $x$ & & \\
\hline & & $\begin{array}{l}\text { Endogenous: Articulation of a 'guiding vision' (P); } \\
\text { top-down incentives for change to overcome } \\
\text { entrenched world views }(R, N) \text {; offset the } \\
\text { additional transaction costs of polycentric } \\
\text { governance systems (R, N) }\end{array}$ & $x$ & & $x$ & $x$ \\
\hline
\end{tabular}

${ }^{a}$ Ex $=$ Exogenous; $\mathrm{En}=$ Endogenous; $\mathrm{Ba}=$ Barriers.

${ }^{\mathrm{b}} \mathrm{R}=$ Resources; $\mathrm{L}=$ Legitimacy; $\mathrm{P}=$ Processes; $\mathrm{N}=$ Norms 


\section{Annex 5. Indicators of transformational change by context and scale of action}

This table provides examples of indicators of transformational change, as identified by the authors of each study. We classify these into driver groups: R (Resources), L (Legitimacy), P (Process) and N (Norms), as well as $\mathrm{O}$ (Outcome indicators). The theoretical basis of each study was identified from each study's methods, as described in the article.

\begin{tabular}{|c|c|c|c|c|c|c|}
\hline \multirow[t]{2}{*}{ Context and scale } & \multirow[t]{2}{*}{ Indicators } & \multicolumn{3}{|c|}{$\begin{array}{l}\text { Driver } \\
\text { groups }^{\mathrm{b}}\end{array}$} & \multirow[t]{2}{*}{$\mathrm{O}^{1}$} & \multirow[t]{2}{*}{ Theoretical basis } \\
\hline & & $\mathbf{R}$ & $\mathrm{L}$ & $P$ & & \\
\hline \multirow[t]{10}{*}{$\begin{array}{l}\text { Climate change } \\
\text { adaptation - local }\end{array}$} & $\begin{array}{l}\text { Rights and responsibilities distributed fairly [N: } \\
\text { fairness] }\end{array}$ & & & & $x$ & \multirow{2}{*}{$\begin{array}{l}\text { Substantive } \\
\text { justice; } \\
\text { procedural justice } \\
\text { (Holland 2017) }\end{array}$} \\
\hline & $\begin{array}{l}\text { Decisions made through just institutional } \\
\text { processes and procedures [N: justice] }\end{array}$ & & & & $x$ & \\
\hline & $\begin{array}{l}\text { Shift in cropping systems; farmers' efforts to } \\
\text { cope with periodic climate fluctuations and } \\
\text { hazards in extreme years are transformed [0: } \\
\text { adopt new technology] }\end{array}$ & & & & $x$ & \multirow[t]{8}{*}{$\begin{array}{l}\text { Systems theory; } \\
\text { organizational } \\
\text { theory (Mapfumo } \\
\text { et al. 2017) }\end{array}$} \\
\hline & $\begin{array}{l}\text { Local awareness about limitations of current } \\
\text { cropping systems [R: information; P: } \\
\text { awareness raising] }\end{array}$ & $x$ & & $x$ & & \\
\hline & $\begin{array}{l}\text { Farmer experimentation with new options [P: } \\
\text { learning; N: will to innovate and learn] }\end{array}$ & & & $x$ & $x$ & \\
\hline & $\begin{array}{l}\text { Strength and dynamism of local institutions } \\
\text { that support ongoing change processes [R: } \\
\text { institutions: N: participative, dynamic] }\end{array}$ & $x$ & & & $x$ & \\
\hline & $\begin{array}{l}\text { Extent of local partnerships between } \\
\text { men and women, and traditional and local } \\
\text { administrative leaders [L: social, political; P: } \\
\text { partnership; N: participative] }\end{array}$ & & $x$ & $x$ & $x$ & \\
\hline & $\begin{array}{l}\text { Promotion of information and knowledge } \\
\text { sharing is present [P: knowledge sharing; N: } \\
\text { will to learn] }\end{array}$ & & & $x$ & & \\
\hline & $\begin{array}{l}\text { Adoption of new crop varieties [0: adopt new } \\
\text { technology] }\end{array}$ & & & & $x$ & \\
\hline & $\begin{array}{l}\text { Source of driver for the change process is } \\
\text { endogenous and local, instead of exogenous } \\
\text { and non-local [N: endogenous change] }\end{array}$ & & & & $x$ & \\
\hline
\end{tabular}




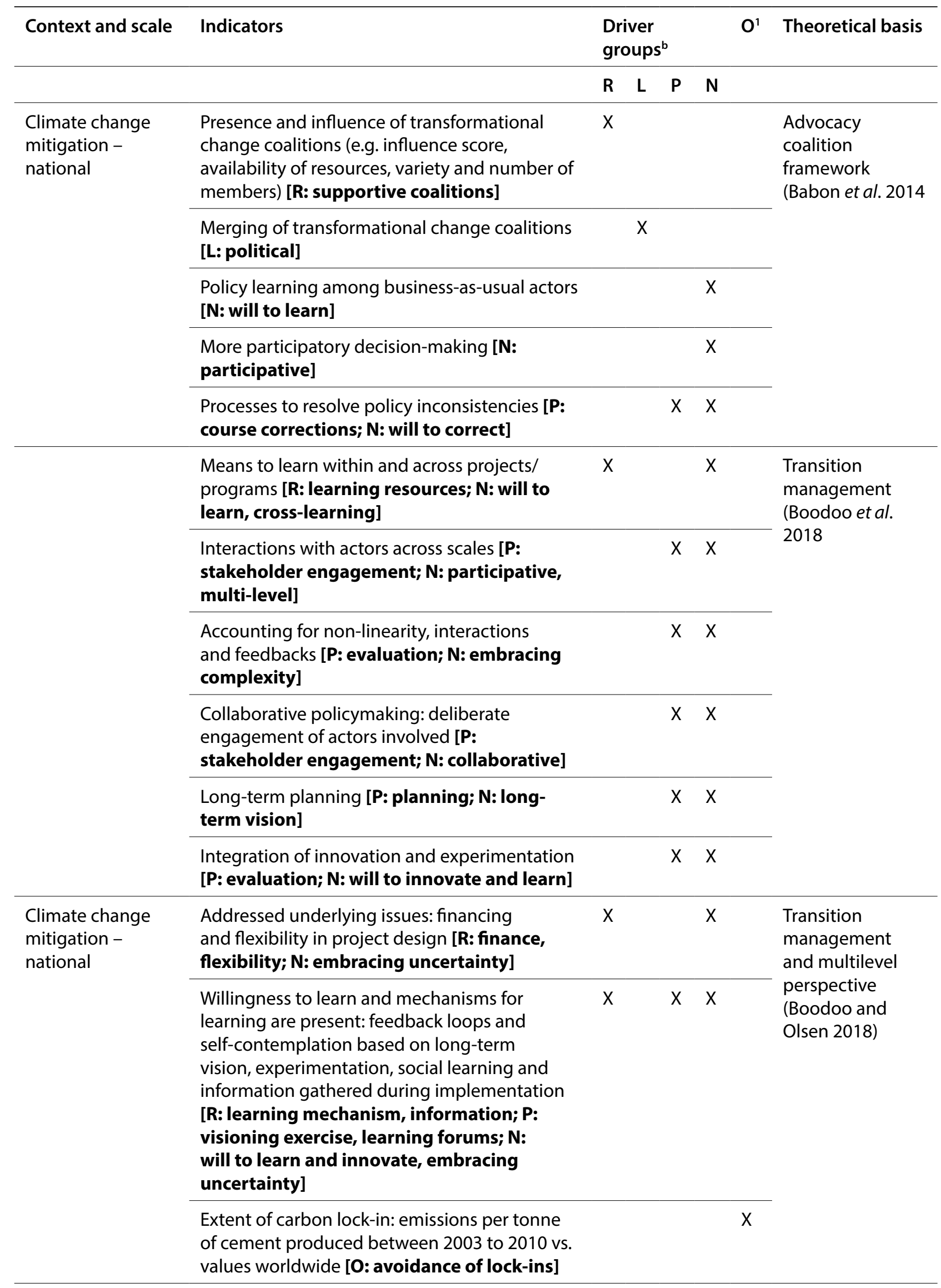




\begin{tabular}{|c|c|c|c|c|c|c|c|}
\hline \multirow[t]{2}{*}{ Context and scale } & \multirow[t]{2}{*}{ Indicators } & \multicolumn{4}{|c|}{$\begin{array}{l}\text { Driver } \\
\text { groups }^{\mathbf{b}}\end{array}$} & \multirow[t]{2}{*}{$\mathbf{O}^{1}$} & \multirow[t]{2}{*}{ Theoretical basis } \\
\hline & & $\mathbf{R}$ & $\mathbf{L}$ & $\mathbf{P}$ & $\mathbf{N}$ & & \\
\hline & $\begin{array}{l}\text { Sensitivity of fertilizer supply to global prices of } \\
\text { phosphorus [L: economic] }\end{array}$ & & $x$ & & & & \multirow{10}{*}{$\begin{array}{l}\text { Transition } \\
\text { management; } \\
\text { economics } \\
\text { of increasing } \\
\text { returns (Jacobs et } \\
\text { al. 2017). }\end{array}$} \\
\hline & $\begin{array}{l}\text { Persistence of environmental problems } \\
\text { associated with phosphorus [L: social, } \\
\text { economic] }\end{array}$ & & $x$ & & & & \\
\hline & $\begin{array}{l}\text { Efficiency and retention of phosphorus in food } \\
\text { production [L: food security] }\end{array}$ & & $\mathrm{X}$ & & & & \\
\hline & $\begin{array}{l}\text { Number of years until demand for high-grade } \\
\text { mined phosphorous exceeds supply [0: } \\
\text { resource sustainability] }\end{array}$ & & & & & $x$ & \\
\hline & $\begin{array}{l}\text { Availability of technological or biological } \\
\text { substitute for phosphorus [R: technology] }\end{array}$ & $x$ & & & & & \\
\hline & $\begin{array}{l}\text { Risk aversion in management [N: embracing } \\
\text { uncertainty] }\end{array}$ & & & & $x$ & & \\
\hline & Connectivity across policies [N: multi-sector] & & & & $x$ & & \\
\hline & $\begin{array}{l}\text { Environmental health [0: environmental } \\
\text { quality] }\end{array}$ & & & & & $x$ & \\
\hline & $\begin{array}{l}\text { Whether there is a circular phosphorus } \\
\text { economy [0: sustainability] }\end{array}$ & & & & & $x$ & \\
\hline & $\begin{array}{l}\text { The rate of phosphate rock consumption [0: } \\
\text { sustainability] }\end{array}$ & & & & & $x$ & \\
\hline \multirow{2}{*}{$\begin{array}{l}\text { Sustainable } \\
\text { resource } \\
\text { management - } \\
\text { local }\end{array}$} & $\begin{array}{l}\text { Level of degradation of the water catchment } \\
\text { [L: society; O: sustainability] }\end{array}$ & & $\mathrm{L}$ & & & $X$ & \multirow{2}{*}{$\begin{array}{l}\text { Integrated water } \\
\text { management } \\
\text { / transition } \\
\text { management } \\
\text { (Bos et al. 2015) }\end{array}$} \\
\hline & $\begin{array}{l}\text { Level of integration across stakeholders } \\
\text { [P: multi-stakeholder processes; N: } \\
\text { participative, multi-sector] }\end{array}$ & & & & $X$ & & \\
\hline \multirow{4}{*}{$\begin{array}{l}\text { Sustainable } \\
\text { resource } \\
\text { management - } \\
\text { multi-level }\end{array}$} & $\begin{array}{l}\text { Changes in perspective and knowledge; [N: } \\
\text { will to learn; } \mathbf{O} \text { : change in perspective and } \\
\text { knowledge] }\end{array}$ & & & & $\mathrm{X}$ & $x$ & \multirow[t]{2}{*}{$\begin{array}{l}\text { Collective } \\
\text { learning (Brown } \\
\text { and Harris } 2014\end{array}$} \\
\hline & $\begin{array}{l}\text { Integration of different perspectives [P: multi- } \\
\text { stakeholder processes; N: participation, } \\
\text { respecting diversity] }\end{array}$ & & & & $\mathrm{X}$ & & \\
\hline & $\begin{array}{l}\text { Level of scientific evidence for the importance } \\
\text { of soil health in rangeland management [R: } \\
\text { information; L: scientific] }\end{array}$ & $x$ & $x$ & & & & \multirow{2}{*}{$\begin{array}{l}\text { [Theoretical basis } \\
\text { not mentioned] } \\
\text { (Derner et al. } \\
\text { 2018) }\end{array}$} \\
\hline & $\begin{array}{l}\text { Value of the study of soil health among } \\
\text { students oriented towards production/ } \\
\text { maximization [L: practitioners] }\end{array}$ & & $x$ & & & & \\
\hline
\end{tabular}

${ }^{1} \mathrm{R}=$ Resources $\mathrm{L}=$ Legitimacy $; \mathrm{P}=$ Processes $\mathrm{N}=$ Norms; $\mathrm{O}=$ Outcome indicators 


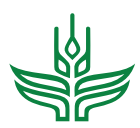

CGIAR
RESEARCH

PROGRAM ON

Forests, Trees and

Agroforestry
The CGIAR Research Program on Forests, Trees and Agroforestry (FTA) is the world's largest research for development program to enhance the role of forests, trees and agroforestry in sustainable development and food security and to address climate change. CIFOR leads FTA in partnership with Bioversity International, CATIE, CIRAD, ICRAF, INBAR and TBI.

FTA's research is supported by CGIAR Fund Donors: cgiar.org/funders/

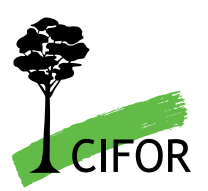

Center for International Forestry Research (CIFOR) advances human well-being, equity and environmental integrity by conducting innovative research, developing partners' capacity, and actively engaging in dialogue with all stakeholders to inform policies and practices that affect forests and people. CIFOR is a CGIAR Research Center, and leads the CGIAR Research Program on Forests, Trees and Agroforestry (FTA). Our headquarters are in Bogor, Indonesia, with offices in Nairobi, Kenya; Yaounde, Cameroon; Lima, Peru and Bonn, Germany. 